Article

\title{
Demise of the Planktic Foraminifer Genus Morozovella during the Early Eocene Climatic Optimum: New Records from ODP Site 1258 (Demerara Rise, Western Equatorial Atlantic) and Site 1263 (Walvis Ridge, South Atlantic)
}

\author{
Roberta D'Onofrio $^{1, *}$, Valeria Luciani ${ }^{1}$, Gerald R. Dickens ${ }^{2} \mathbb{D}$, Bridget S. Wade ${ }^{3}(\mathbb{D})$ and \\ Sandra Kirtland Turner ${ }^{4}$ \\ 1 Department of Physics and Earth Sciences, Ferrara University, via G. Saragat 1, 44121 Ferrara, Italy; \\ valeria.luciani@unife.it \\ 2 Department of Earth, Environmental and Planetary Sciences, Rice University, Houston, TX 77005, USA; \\ jerry@rice.edu \\ 3 Department of Earth Sciences, University College London, Gower Street, London WC1E 6BS, UK; \\ b.wade@ucl.ac.uk \\ 4 Department of Earth Sciences, University of California, Riverside, Riverside, CA 92521, USA; \\ sandra.kirtlandturner@ucr.edu \\ * Correspondence: roberta.donofrio@unife.it
}

Received: 15 January 2020; Accepted: 17 February 2020; Published: 27 February 2020

\begin{abstract}
Here we present relative abundances of planktic foraminifera that span the Early Eocene Climatic Optimum (EECO) at Ocean Drilling Program (ODP) Site 1258 in the western equatorial Atlantic. The EECO ( 53.3-49.1 Ma) represents peak Cenozoic warmth, probably related to high atmospheric $\mathrm{CO}_{2}$, and when planktic foraminifera, a dominant component of marine sediment, exhibit a major biotic response. Consistent with previous work, the relative abundance of the genus Morozovella, which dominated early Paleogene tropical-subtropical assemblages, markedly and permanently declined from a mean percentage of $\sim 32 \%$ to less than $\sim 7 \%$ at the beginning of the EECO. The distinct decrease in Morozovella abundance occurred at Site 1258 within 20 kyr before a negative excursion in $\delta^{13} \mathrm{C}$ records known as the J event and which defines the beginning of EECO. Moreover, all morozovellid species except $M$. aragonensis dropped in abundance permanently at Site 1258, and this is related to a reduction in test-size. Comparing our data with that from other locations, the remarkable switch in planktonic foraminifera assemblages appears to have begun first with unfavourable environmental conditions near the Equator and then extended to higher latitudes. Several potential stressors may explain observations, including some combination of algal photosymbiont inhibition (bleaching), a sustained increase in temperature, or an extended decrease in $\mathrm{pH}$.
\end{abstract}

Keywords: Early Eocene Climatic Optimum; planktic foraminiferal changes; bulk carbon isotopes; Morozovella decline; Atlantic Ocean; paleobiogeography; Morozovella test-size reduction

\section{Introduction}

The dynamic climate of the early Paleogene represents an exceptionally interesting time of Earth's history because it illustrates Earth system responses to high global temperatures. Beginning about 59 million years ago $(\mathrm{Ma})$, temperatures across Earth's surface slowly rose toward the Early Eocene Climatic Optimum (EECO), an extended interval of peak Cenozoic global warmth that occurred 
approximately from 53.3 to $49.1 \mathrm{Ma}$ [1-3]. Average high-latitude and deep-ocean temperatures during the EECO likely exceeded those at present day by at least $10^{\circ} \mathrm{C}[1,4-8]$. Superimposed on this long-term early Paleogene warming, but also during the EECO, several short-term ( 40-200 kyr duration) global warming episodes occurred [2,9-19]. These events are now generally referred to as hyperthermals. Considerable current study of the EECO and the hyperthermals exists because inferred changes in temperature somehow relate to major changes in carbon cycling. This is especially true for the most prominent hyperthermal, the Paleocene-Eocene Thermal Maximum (PETM, 56 Ma) [20-23].

While root causes for the EECO and the hyperthermals remain a source of debate, it is clear that biota, both on land and in the sea, were impacted significantly [24-35]. This includes planktic foraminifera, the tests of which form a common component of many marine sediment records since the Cretaceous. In particular, a major turnover between two dominant genera, Morozovella and Acarinina, occurred at multiple sites (Figure 1) near the onset of the EECO; more specifically, the abundance and diversity of Morozovella decreased significantly while the abundance and diversity of Acarinina increased significantly [19,36-42]. At multiple locations in the northern hemisphere with paleo-latitudes of about $30^{\circ} \mathrm{N}$, this "switch" happened rapidly and very close to the J event (e.g., [19,41-43]), a possible hyperthermal that happened at $\sim 53.3 \mathrm{Ma}$ [2]. However, at Site 1263, with a paleo-latitude of about $30^{\circ} \mathrm{S}$ in the Atlantic, the morozovellid decline seems to have happened $\sim 165 \mathrm{kyr}$ after the J event.

Reconstructing a more complete scenario of the planktic foraminiferal response during the EECO requires data from an equatorial site. Previous work at Ocean Drilling Program (ODP) Site 1258 on Demerara Rise in the equatorial Atlantic Ocean (Figure 1) has documented a fairly complete lower Eocene carbonate-rich interval containing abundant and well-preserved planktic foraminifera [44]. However, the planktic foraminiferal assemblages have not been studied in any detail so far. Here, we generate new planktic foraminiferal assemblage records in lower Eocene sediment at Site 1258. The new results provide important insights on the timing and causes of the Morozovella/Acarinina abundance switch and the overall morozovellid species decline.

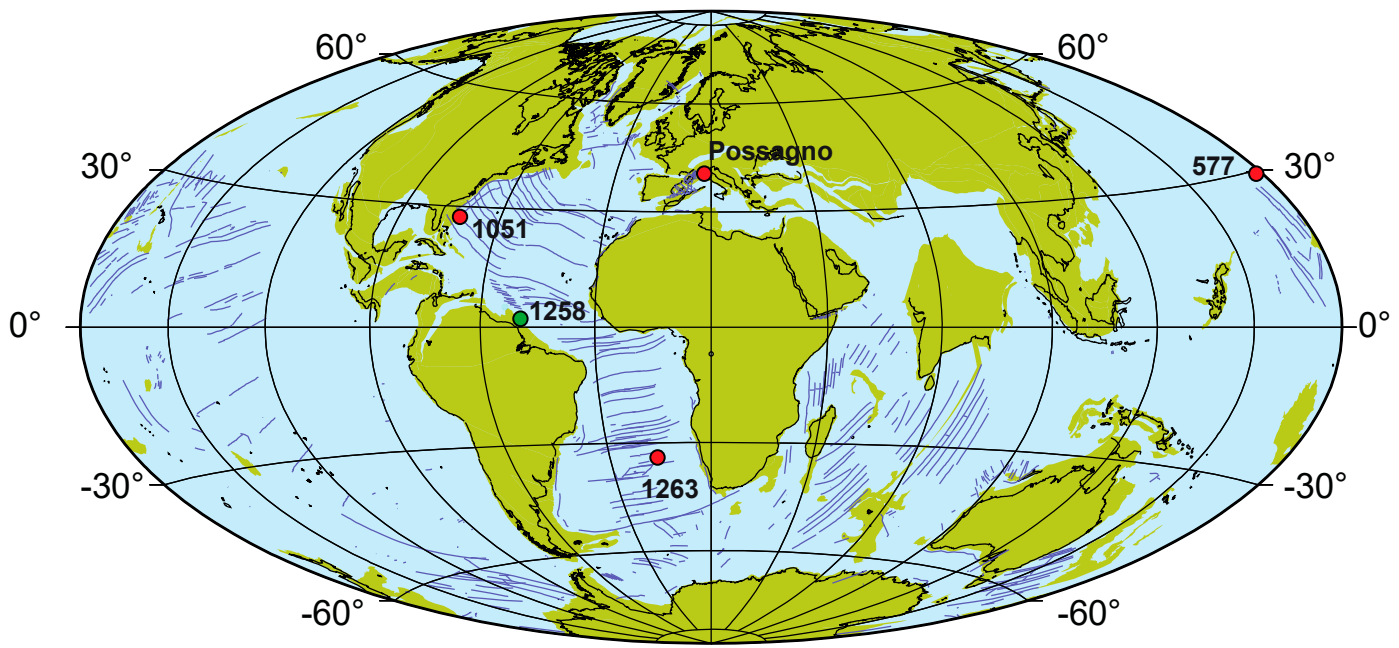

Figure 1. Approximate location of Site 1258 during the early Eocene (green dot). Also shown are locations of Deep Sea Drilling Project (DSDP) Site 577, Ocean Drilling Program (ODP) Sites 1051 and 1263, and the Possagno section (red dots), which each have bulk carbonate $\delta^{13} \mathrm{C}$ and planktic foraminiferal records spanning the Early Eocene Climatic Optimum (EECO) (e.g., [19,41,42]). Base map is from http://www.odsn/de/services/paleomap.html with paleolatitudes modified for Sites 577, 1051 and 1258 according to www.paleolatitude.org model version 1.2 [45]. Possagno paleolatitude is based on the http://www.odsn.de/odsn/services/paleomap/adv_map.html model. Note that locations might be adjusted to a different reference frame to account for changes in plate motion relative to the spin axis [3]. 


\section{ODP Site 1258: Location and Previous Work}

ODP Site 1258 is located north of Suriname, South America, at $9^{\circ} 26^{\prime} \mathrm{N}$ latitude, $54^{\circ} 44^{\prime}$ W longitude and $3192 \mathrm{~m}$ below sea level. Importantly, the site lies on the northwest-facing slope of a small promontory of Demerara Rise [44]. This rise is underlain by continental crust of South America thinned in the early Cretaceous, which allows for straightforward paleo-positions of Site 1258 since the middle Cretaceous. During the early Eocene, the latitude was $\sim 1^{\circ} \mathrm{S}$ and the water depth was $\sim 3000 \mathrm{~m}[44,46]$.

Three holes (A, B, C) were drilled via the rotary coring method at Site 1258. The total section recovered includes $485 \mathrm{~m}$ of sedimentary rock, which has been divided into several lithologic units and subunits [44]. Somewhat unusual for a pelagic setting, most of the middle to late Cenozoic is absent, except for an uppermost $<8 \mathrm{~m}$ thick Miocene interval (Unit I). Of interest to this study is Unit IIA, which spans from about 6 to 241 metres below seafloor (mbsf). Unit IIA is described as foraminiferal-nannofossil chalk, with samples averaging about $\sim 60 \% \mathrm{CaCO}_{3}$ by weight [44]. The lithologic description relates to the relatively abundances of nannofossils and planktic foraminifers, the latter which comprise about $10-25 \%$ by volume.

Chalk in the marine environment often forms when pelagic carbonate ooze is buried several hundred meters below the seafloor and its constituent components (nannofossils and planktic foraminifers) experience local dissolution and re-precipitation of calcite. Consistent with this general view, shipboard observations indicate that nannofossils and planktic foraminifers of Unit IIA have moderate preservation [44].

Unit IIA spans from middle Eocene to late Paleocene in age [44]. This is known from shipboard magnetostratigraphy and biostratigraphy, which express polarity chrons C20r through C26n, calcareous nannofossil biozones NP15 through NP5 [47], and planktic foraminifera biozones P11 through P4a [48].

Even though recovered by the rotary method, cores across Unit IIA at the three holes at Site 1258 can be aligned through records of physical properties [44]. Such alignment leads to a "revised meter composite depth" (rmcd) scale. From the stratigraphy and the spliced records, most of the early Eocene sedimentary record appears continuous with an average compacted sedimentation rate of $15 \mathrm{~m} / \mathrm{Myr}$ [44].

A detailed bulk carbonate $\delta^{13} \mathrm{C}$ record has been generated across part of the early Eocene at Site 1258 [15]. Similar to other early Eocene marine sections from around the world, the record shows a series of negative carbon isotope excursions (CIEs) with specific stratigraphic positioning relative to polarity chrons and key nannofossil datums [49] (Figure 2). For the nomenclature of the CIEs, we use the most current scheme [2]. With the $\delta^{13} \mathrm{C}$ record and existing biostratigraphy, a precise age model can be generated [15]. Following previous work at Site 1258, we have retained ages on the Option 1 (Wo-1) time scale [50], which was generated by correlating the long ( $400 \mathrm{kyr})$ eccentricity cycle identified from high-resolution X-ray Fluorescence Fe (iron) counts to the La2010d solution [51]. We recognize that subtle ( $<400 \mathrm{kyr}$ ) offsets exist between absolute ages of events during the Early Eocene, depending on the time scale utilized. However, relative ages of recent time scales, including Wo-1, are much more precise. In summary, Site 1258 provides an ideal location to examine Early Eocene changes in planktonic foraminifera near the paleo Equator and at fairly high resolution. 


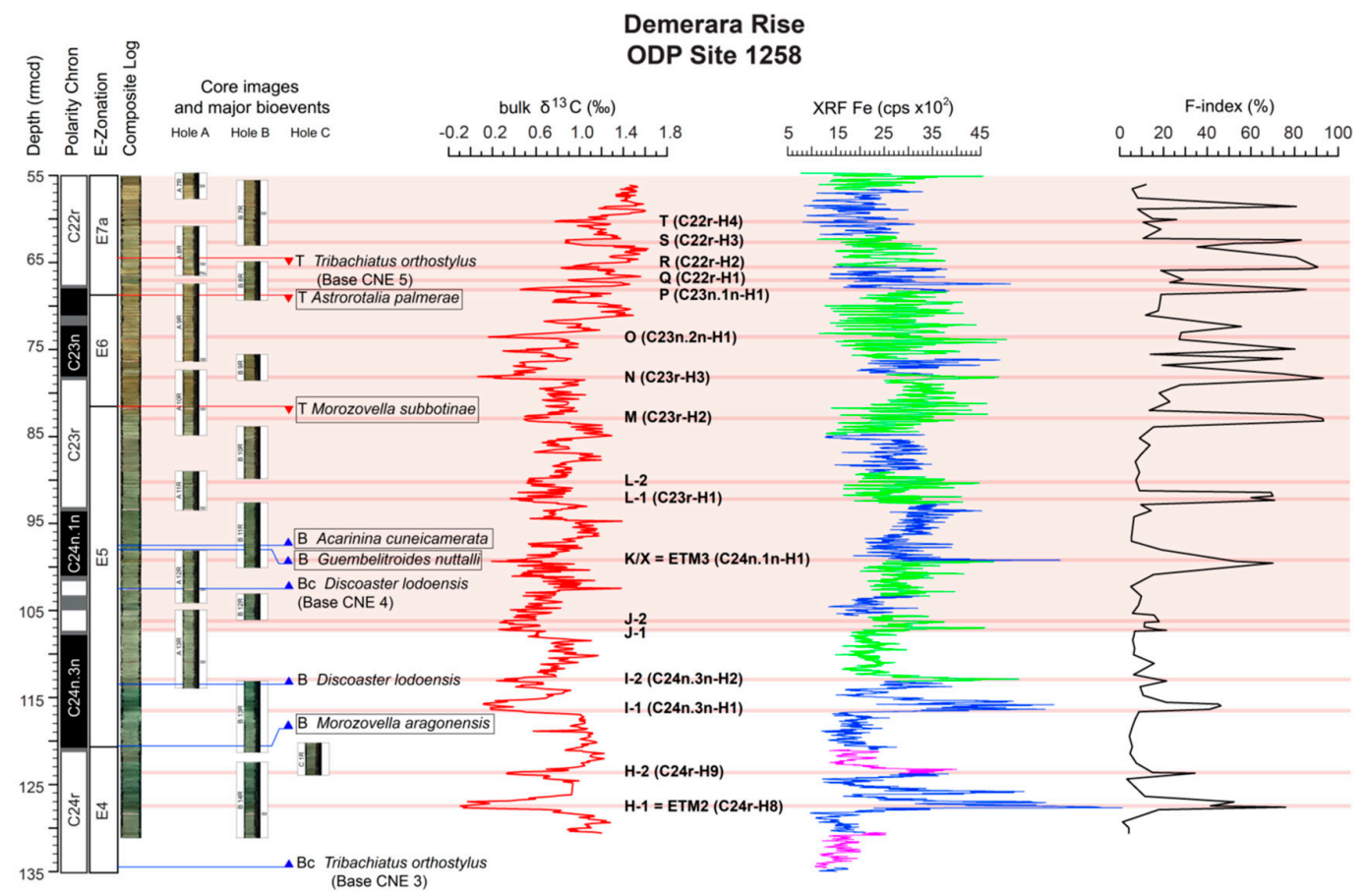

Figure 2. Photographs of individual sediment cores from Holes A, B, C (photograph are located at http://iodp.tamu.edu/janusweb/imaging/photo.cgi) along with the composite log, the planktic foraminifera E Zonation scheme [52] as modified by [53], plotted against bulk stable carbon isotopes [15], XRF (X-ray Fluorescence) Fe contents [49], and fragmentation index (this work). Also shown are the positions of significant planktic foraminiferal (this work, within boxes) and calcareous nannofossil biohorizons [49]. The main carbon isotope excursions (CIEs) are labelled according to [2,15,18].

\section{Materials and Methods}

\subsection{Early Eocene Sampling Strategy at Site 1258}

The succession examined here at Site 1258 spans the interval from 56.05 to 130.58 rmcd. This depth range includes the T through H-1 CIEs (Figure 2), and accumulated between $\sim 49.6$ to $\sim 53.8 \mathrm{Ma}$ on the Wo-1 time scale [50]. In an effort to get a fairly high-resolution and complete record, we obtained samples from Hole $1258 \mathrm{~A}$, Hole $1258 \mathrm{~B}$ and Hole $1258 \mathrm{C}$. Sample spacing varied from $\sim 50 \mathrm{~cm}$ across some intervals to $\sim 5.0 \mathrm{~cm}$ across several of the CIEs. Such spacing gives nominal ages between samples of $\sim 80 \mathrm{kyr}$ to $\sim 5 \mathrm{kyr}$. A total of 148 samples were collected.

\subsection{Proxy for Carbonate Dissolution: Fragmentation Index}

Deep-sea carbonate dissolution, which coincided with at least several of the early Eocene negative CIEs [54-57], causes planktic foraminifera to break into fragments when they begin to dissolve [58-60]. We adopt the fragmentation index (F index) as a carbonate dissolution proxy. This proxy (expressed as a percentage) is calculated according to [58]: the ratio between fragments or partially dissolved planktic foraminiferal tests versus entire tests on $~ 300$ elements. The fragmented tests include all planktic foraminiferal specimens showing missing or deteriorated chambers and substantial breakage. F indexes were evaluated from a total of 100 samples. Data are available in Table S1.

\subsection{Planktic Foraminiferal Analysis}

Planktic foraminifera were observed in washed residues prepared by immersing previously freeze-dried samples in deionized water. When disaggregated, samples were washed over a $>63 \mu \mathrm{m}$ sieve. Washed residues were dried at $<50{ }^{\circ} \mathrm{C}$. The sieve was immerged in a methylene blue bath after 
each washing in order to colour planktic foraminifera potentially trapped in the mesh [61]. This is an easy method to exclude possible contamination amongst successive samples.

Relative abundances of planktic foraminiferal genera and a number of species, as well as the species from genus Morozovella were determined for the $>63 \mu \mathrm{m}$ size fraction from random splits using a Micro Riffle Splitter Gilson SP-171X. The counting was achieved on a statistical population of $\sim 300$ specimens for the genera and species shown in Figure 3 whereas the counting of the Morozovella species abundance was carried out on a mean number of 170 Morozovella specimens (Tables S2 and S3). Considering that morozovellids were rare above their decline in abundance and across most hyperthermals, it was not possible to perform the counting on a population of $\sim 300$ specimens for all the samples.

For counting, we kept specimens of Subbotina senni separate from other subbotinids, because this taxon likely occupied a different habitat [38,41,62-64]. Specifically, S. senni is considered a mixed-layer form that sank to middle mixed-layer or deeper depths during gametogenesis (e.g., $[38,63]$ and references therein). The taxonomic criteria adopted in this study follow $[38,65]$. Quantitative data are available in Table S1. In addition to the above counting, from 14 samples distributed from the base to the N CIE (130.58 rmcd-77.8 rmcd), we assessed the variation in morozovellid test size. Size fraction counts were performed on the same morozovellids used for quantitative analysis (an average of $\sim 170$ individuals) but "only" on the larger fraction $(>200 \mu \mathrm{m})$. We obtained three classes of size fractions $(200-250 \mu \mathrm{m}, 250-300 \mu \mathrm{m}$ and $>300 \mu \mathrm{m})$ through the use of appropriate sieves and analyzed the entire morozovellid assemblages exceeding the $200 \mu \mathrm{m}$.

The relative abundance of planktic foraminiferal genera from south Atlantic Site 1263 (Walvis Ridge) across the EECO has been assessed previously [42]. However, changes in single species of Morozovella were absent. In order to have a more exhaustive scenario of the morozovellid crisis at the EECO across the Atlantic Ocean, we estimated here the relative abundance of Morozovella species also from this South Atlantic site. The interval adopted is the same studied by [42], i.e., from 240.52 rmcd to $297.168 \mathrm{rmcd}$ with sample spacing varying from $\sim 100 \mathrm{~cm}$ to $\sim 30 \mathrm{~cm}$. The same test size estimation of Morozovella species was performed also from Site 1263 from 13 samples from 292.19 rmcd to 262.24 rmcd (Table 1).

\section{Results}

\subsection{Variations in Dissolution Proxy}

The F index record exhibits a somewhat bimodal pattern (Figure 2, Table S1). Many samples have value on a "background" trend, which generally increases after the $\mathrm{K} / \mathrm{X}$ event but remains $<10 \%$. However, across numerous CIEs, F index exceeds 70\%. In our record, the ETM2, H2, I1, I2, J1, J2, K/X, L1, L2, M, N, O, P, R, S and U events have, respectively, maximum F index values of $75.9 \%, 15 \%, 46.3 \%$, $21.4 \%, 21.33 \%, 18 \%, 70.1 \%, 70.9 \%, 70.1 \%, 93.3 \%, 93.1 \%, 80.2 \%, 85.3 \%, 90.6 \%, 83 \%, 80.8 \%$. With the exception of ETM2 (75.9\%), the F index values appear more extreme across the CIEs in the upper part of the studied succession that corresponds to higher "background" values.

\subsection{Biostratigraphy}

Planktic foraminifera throughout the interval here analysed exhibit a 'frosty' instead of a 'glassy' appearance, sensu [46]. However, despite test recrystallization, species can be readily identified. Analysis of planktic foraminifera across the studied interval at Site 1258 allows identification of three zonal boundaries within the current low-latitude planktic foraminifera biozone scheme of [52] as modified by [53]. These are (Figure 2) the lowest occurrence (Base $=\mathrm{B}$ ) of Morozovella aragonensis (E4/E5 boundary) at $120.65 \mathrm{rmcd}$; highest occurrence (Top = T) of Morozovella subbotinae (E5/E6) at $81.51 \mathrm{rmcd}$; and, B of Astrorotalia (Planorotalites) palmerae at $68.68 \mathrm{rmcd}$ (E6/E7a). The B of Turborotalia frontosa, which marks the E7a/E7b boundary, was not recorded, so must lie above the studied interval. 
Because the early Eocene section at Site 1258 has a detailed $\delta^{13} \mathrm{C}$ record and because we have sampled the sequence at fairly high resolution, four additional observations regarding relative dating can be made. At Site 1258 (Figure 2):

- $\quad$ the B of $M$. aragonensis lies $4.85 \mathrm{~m}$ below the I-1 CIE that is at $115.8 \mathrm{rmcd}$;

- the T of M. subbotinae lies $1.49 \mathrm{~m}$ above the M CIE that is at $83.0 \mathrm{rmcd}$;

- the B of Acarinina cuneicamerata, the suggested marker for the E6/E7a boundary [52], is found at $97.53 \mathrm{rmcd}, 5.4 \mathrm{~m}$ below the L1 that is at 92,13 rmcd CIE and well below the T of M. subbotinae;

- the B of Guembelitrioides nuttalli, which sets the E7b/E8 boundary in the middle Eocene [63,65], is found at $98.03 \mathrm{rmcd}$ and $1.32 \mathrm{~m}$ above the K/X CIE (99.35 rmcd).

\subsection{Variations in Abundance of Planktic Foraminiferal Genera}

Planktic foraminiferal assemblages, beyond biostratigraphic interest, display both long-term and transient changes across the early Eocene investigated interval at Site 1258 (Figure 3, Table S1). The major change involves the two mixed-layer dwelling genera, morozovellids and acarininids $[38,62,63]$. A strong and permanent reduction in morozovellid abundance occurred over a short depth interval $(<1 \mathrm{~m})$ centred at $107.87 \mathrm{rmcd}$, where mean values of $\sim 32 \%$ in samples below drop to mean value of $\sim 7 \%$ in samples above. This change in relative abundance mostly relates to an increase in the amount and diversity of acarininids, and closely corresponds to but slightly precedes the J-1 CIE. Acarinina comprises a mean value of $\sim 51 \%$ of assemblages below the start of EECO, but about $\sim 72 \%$ above. Conversely, the genera Subbotina and Parasubbotina do not show appreciable changes in abundance across the J CIE (Figure 3).

The three dominant genera, Morozovella, Acarinina and Subbotina also display high-frequency variations in abundance superimposed on long-term trends. In general, short-term fluctuations in the abundance of Acarinina coincide with contrasting abundance changes of Morozovella and subbotinids. This relationship is particularly evident across the CIEs, where acarininid abundances generally increase to comprise up to $>90 \%$ of the total assemblage. Interestingly, abundances of morozovellids and subbotinids often recover rapidly above the CIEs (Figure 3). It should be recognized, however, that the above changes in abundances reflect a closed-sum effect, where the drop in one genus necessarily relates to a rise in one or more other genera. However, the acarininid dominance across the CIEs appears as a real response to the hyperthermals in the mixed layer, as documented also in several Tethyan successions (as discussed below).

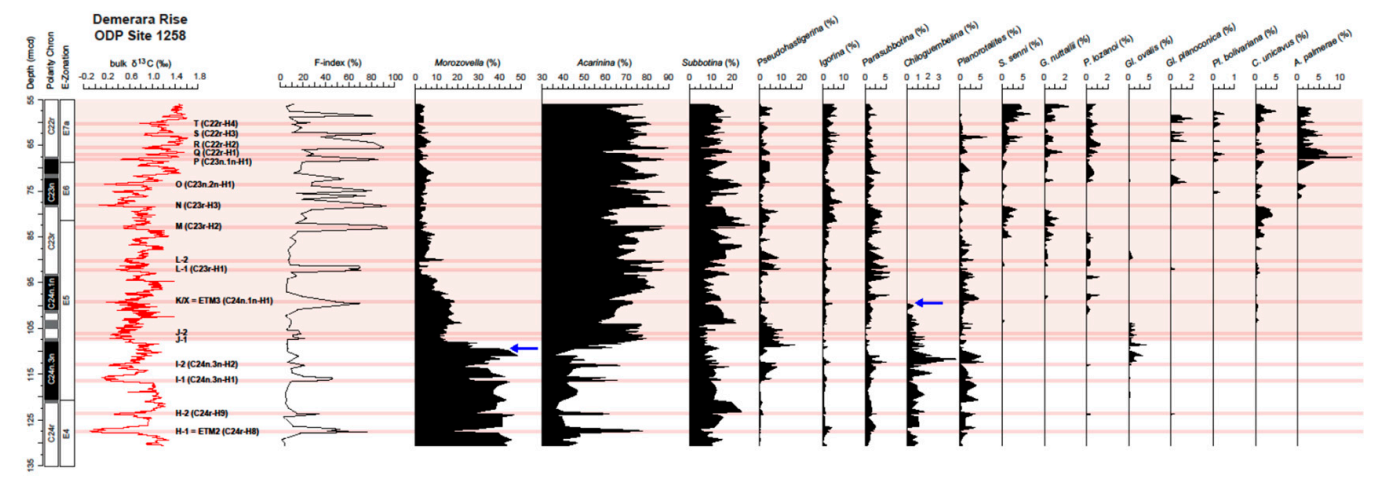

Figure 3. Bulk sediment stable carbon isotope data plotted versus the F-index and the relative abundances of planktic foraminiferal genera and species across the early Eocene interval at ODP Site 1258. Note (1) the major switch in Morozovella abundance slightly below the J event (blue arrow) and (2) the virtual disappearance of chiloguembelinids below the K/X event (blue arrow). Other information is consistent with Figure 2. 
Minor components of planktic foraminiferal assemblages, such as Pseudohastigerina, Igorina, Parasubbotina, Planorotalites, Subbotina senni, Guembelitroides nuttalli, Praemurica lozanoi, globanomalinids, Pseudoglobigerinella bolivariana, Catapsydrax unicavus and Astrorotalia palmerae never exceed $5 \%$ in terms of total planktonic foraminifera abundance except for a peak (10\%) of A. palmerae at the P CIE (Figure 3, Table S1). These taxa do not display particular trend throughout. An exception is represented by Chiloguembelina that shows a permanent drop in the earlier part of the EECO (Figure 3, Table S1). Mean abundances of this group are $\sim 1 \%$ in the pre-EECO interval but drop to zero just below the K/X event from sample $100.06 \mathrm{rmcd}$ and never recovered throughout the interval investigated. The virtual disappearance of chiloguembelinids is significant because it also has been recorded below the $\mathrm{K} / \mathrm{X}$ event at Sites 1051 and 1263 [42,66].

\subsection{Variations in Morozovella Species Abundance and Test Size}

To more fully understand the permanent decline in Morozovella abundance at the onset of the EECO, we measured changes in different species (Figure 4, Table S2). The species M. subbotinae, $M$. marginodentata, and $M$. crater are the most abundant species in samples below the EECO, comprising together on average $\sim 20 \%$ of the total morozovellid population. From sample $\sim 107.87 \mathrm{rmcd}$, their mean abundance drops to $\sim 5 \%$. The species Morozovella aequa, M. lensiformis, M. gracilis, M. caucasica and $M$. formosa are a minor component of the morozovellid population because the percentage of each species is not greater than $5 \%$ with the exception of a M. formosa peak of $\sim 16 \%$ at the H2 CIE. The species $M$. aragonensis is more abundant in the first part of its range (mean value $\sim 6 \%$ ) and it shows a decline from the I2 and J CIEs (mean value $~ 3 \%$ ) and a new increase above the J CIE up to L1 CIE (mean value $\sim 8 \%$ ). Above this interval, $M$. aragonensis abundance stabilizes at $\sim 3 \%$.

Examination of morozovellid test size (Table 1) highlights an interesting change. Specimens in the size fraction between 250 and $300 \mu \mathrm{m}$ average $\sim 21 \%$ below the J CIE, but markedly increase to $\sim 57 \%$ above. Nevertheless, the abundance of the largest fraction analysed $(>300 \mu \mathrm{m})$ drops above the onset of the EECO, from $\sim 29 \%$ to $\sim 21 \%$.

\subsection{Changes in Morozovellid Species Abundance and Test Size from Site 1263}

Data obtained from the South Atlantic Ocean Site 1263 reveal that Morozovella aequa and M. subbotinae are the most abundant species below the EECO reaching a mean percentage together of $13.4 \%$ (Figure 5, Table S3). These species are followed in abundance by $M$. marginodentata, M. lensiformis and $M$. crater $(\sim 10 \%)$. The species M. gracilis, M. formosa, M. aragonensis and M. caucasica are rather rare throughout even though the last three species slightly increase in abundance within the EECO, especially after the O CIE.

The species showing the main drop in abundance $\sim 165 \mathrm{kyr}$ after the J event are Morozovella aequa, M. subbotinae, M. marginodentata and M. gracilis as their relative abundance moves as a whole from $\sim 18 \%$ to $\sim 2.5 \%$.

Changes in morozovellids test size are less evident from Site 1263 compared to sites 1051 and 1258 (Table 1). With respect to the other sites, Site 1263 shows a slight increase in percentage of morozovellids $>300 \mu \mathrm{m}$ fraction that is $16.7 \%$ stratigraphically below the decline in abundance and $19 \%$ above. This is mainly due to the occurrence of large-sized Morozovella aequa. A slight increase of smaller morozovellids $(250-300 \mu \mathrm{m})$ is recorded above the abundance reduction as mean values move from $39.7 \%$ to $45 \%$. The smallest fraction $(200-250 \mu \mathrm{m})$ does not change significantly but it displays increases at the J1 and K/X CIEs and in the upper part of the analysed succession (samples $265.43 \mathrm{rmcd}$, $262.24 \mathrm{rmcd}$ ). 
Table 1. Change in morozovellid test-size across the EECO at Site 1258 (above the dashed line) and 1263 (below the dashed line).

\begin{tabular}{|c|c|c|c|c|}
\hline $\begin{array}{l}\text { Sample Depth } \\
\text { (rmcd) }\end{array}$ & $\begin{array}{l}\text { Morozovellids } \\
>300 \mu \mathrm{m}(\%)\end{array}$ & $\begin{array}{l}\text { Morozovellids } \\
250-300 \mu \mathrm{m}(\%)\end{array}$ & $\begin{array}{l}\text { Morozovellids } \\
200-250 \mu \mathrm{m}(\%)\end{array}$ & Events \\
\hline 77.8 & 47.7 & 42.8 & 8.3 & \\
\hline 98.53 & 32.3 & 60.1 & 7.6 & \\
\hline 100.06 & 24 & 52 & 24 & \\
\hline 106.06 & 24 & 53 & 24 & \\
\hline 107.27 & 9.5 & 21.6 & 68.9 & $\mathrm{~J}-1$ \\
\hline 107.87 & 16.8 & 54.5 & 28.7 & morozovellid abundance decline \\
\hline 108.37 & 22.4 & 37.3 & 40.3 & \\
\hline 112.37 & 4.1 & 19.5 & 76.4 & \\
\hline 116.63 & 27.3 & 37.2 & 35.3 & \\
\hline 267.83 & 14 & 58 & 28 & L-2 \\
\hline 269.33 & 41 & 32 & 27 & L-1 \\
\hline 271.43 & 36 & 53 & 11 & \\
\hline 274.813 & 11 & 45.5 & 44.5 & $\mathrm{~K} / \mathrm{X}$ \\
\hline 277.12 & 13 & 58 & 27 & morozovellid abundance decline \\
\hline 278.128 & 5 & 32 & 63 & \\
\hline 280.77 & 24 & 32 & 43 & $\mathrm{~J}-1$ \\
\hline 283.272 & 24.5 & 42 & 33.5 & \\
\hline 287.309 & 22 & 48 & 30 & $\mathrm{I}-2$ \\
\hline 287.76 & 8 & 40 & 52 & $\mathrm{I}-1$ \\
\hline 292.19 & 17 & 44 & 39 & \\
\hline
\end{tabular}

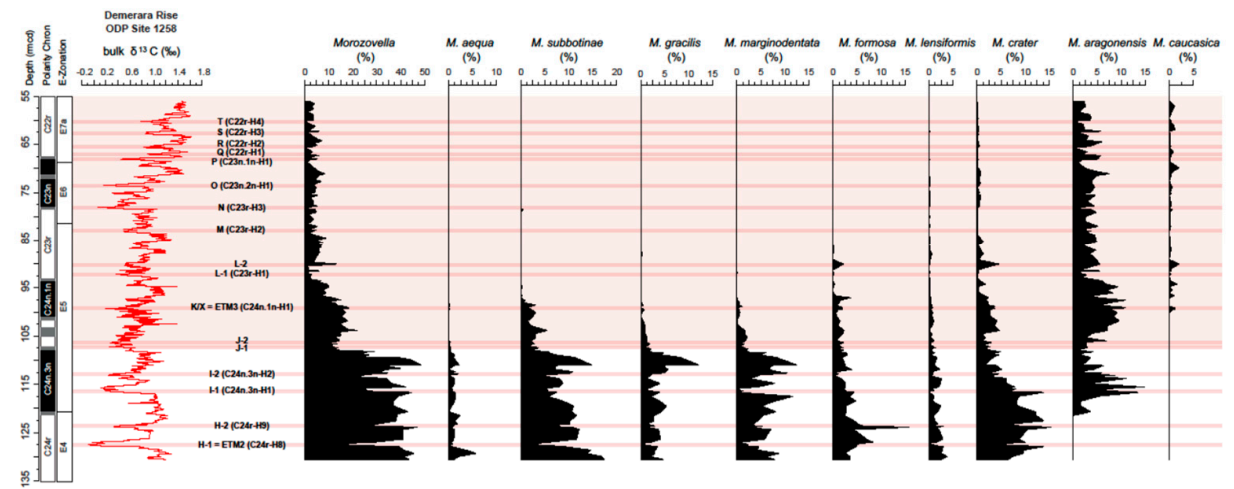

Figure 4. Bulk sediment $\delta^{13} \mathrm{C}$ curve across the early Eocene interval at ODP Site 1258 along with relative abundances of the Morozovella species plotted vs depth. Note that the major permanent decline in Morozovella occurring slightly below the J CIE mainly happens because of reductions in all morozovellid species with the exception of $M$. aragonensis that ranges up to the middle Eocene [38]. Other information is the same as in previous figures. 

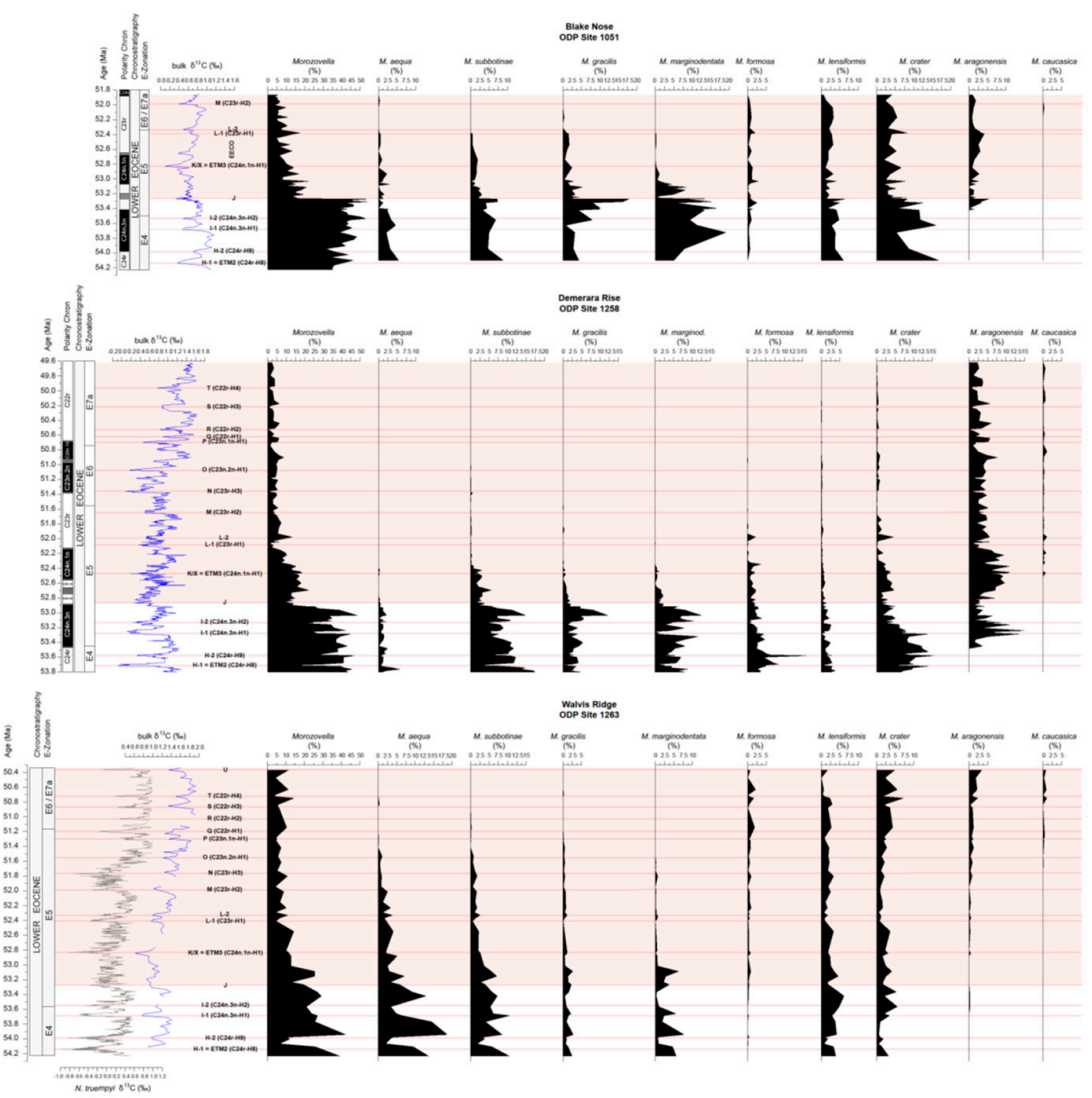

Figure 5. Records of stable carbon isotopes $\left(\delta^{13} \mathrm{C}\right)$ and Morozovella species relative abundance against Age (Ma) from the Atlantic ODP Sites 1051, 1258 and 1263. Bulk sediment $\delta^{13} \mathrm{C}$ from Site 1051 is from [41]. The bulk sediment $\delta^{13} \mathrm{C}$ record from Site 1263 is from [42] (blue) while the benthic foraminiferal (N. truempyi) $\delta^{13} \mathrm{C}$ record comes from [19] (grey). Note that the morozovellid species abundance varies across the sites differently contributing to the permanent decline in abundance of the genus Morozovella.

\section{Discussion}

\subsection{The F-Index Record and Impact of Carbonate Dissolution}

The F-index rises significantly across most of the CIEs at Site 1258, although these increases do not proportionally correspond to CIE magnitude. In fact, the highest F-index values correspond with the relatively modest CIEs in the upper part of the succession studied (Figure 2). A high F index suggests carbonate dissolution because this process breaks planktic foraminifera into fragments [58,59]. Carbonate solubility horizons that impact the balance of calcite preservation and dissolution on the seafloor, expressed in the sediments as the lysocline and the carbonate compensation depth (CCD) shoaled considerably during various hyperthermals of the early Eocene. The three most prominent Paleogene hyperthermals, the PETM, H-1 (ETM2), K/X (ETM3) events were clearly marked by pronounced carbonate dissolution at multiple locations [54-57] as a result of increased inputs of ${ }^{13} \mathrm{C}$-depleted carbon into the ocean and atmosphere $[57,67]$. The increase in maximum F-index values reached during the smaller hyperthermals towards the middle of the EECO suggests an increased intensity of carbonate dissolution (Figure 2) despite apparently smaller carbon input. The baseline F-index also increases slightly across the studied interval, which may suggest a long-term shoaling in the lysocline depth at this location or a deepening of the depositional setting. If Site 1258 were closer to the CCD prior to the EECO hyperthermals, this would increase its susceptibility to carbonate dissolution for a given carbon input. 
Another explanation for the increase in F-index values is that EECO warmth augmented microbial metabolic rates and intensified remineralisation of organic matter within the water column. This would decrease $\mathrm{pH}$ and enhance carbonate dissolution [68-72].

Planktic foraminiferal genera vary in dissolution susceptibility, so carbonate dissolution may lead to deviations in sedimentary planktonic foraminiferal assemblages from the living assemblages. Hence, the recorded assemblage may not simply represent the planktic foraminiferal response to climatic and oceanographic changes. Some studies of latest Paleocene to early Eocene age sediments, including laboratory experiments, suggest a general ordering of dissolution according to genus, with Acarinina more resistant than Morozovella and the latter more resistant than subbotinids [73-75]. The highest F-index values generally correspond at Site 1258 to peaks in the relative abundance of acarininids and low percentage of morozovellids and subbotinids. Changes in carbonate preservation should be the primary driver of the observed planktic foraminiferal assemblages, it follows that the dominance of Acarinina during multiple CIEs could represent a taphonomic artifact. However, high abundances of Acarinina also occur at Site 1258 also across the CIEs that record low F-index values, such as the J-1 and J-2 CIEs. This finding is consistent with records from other locations where CIEs have low F-index and major increases of Acarinina [19]. For example, at the Tethyan Terche section in northern Italy, [76,77] noted pronounced spikes in Acarinina abundance at the ETM2, H1 and I-2 events where planktic foraminiferal assemblages are not biased by dissolution. Despite evidence of carbonate dissolution in the water column at or beneath the seafloor at Site 1258, this process probably only amplified primary changes in planktic foraminiferal assemblages.

The 'background' low F-index values $(<10 \%)$ recorded at Site 1258 may derive from early dissolution in the water column [78] and/or from laboratory processing such as the freeze thaw treatment and the washing procedure from samples difficult to disaggregate that may have caused some crumbling of specimens. This may also explain some anomalously high $\mathrm{F}$ index values not related to CIEs (Figure 2).

\subsection{Problems in Early Eocene Planktic foraminiferal Biozones}

Our new data confirm issues with planktic foraminifera zonal markers across the lower Eocene, as previously highlighted $[19,41,42,53]$. Firstly, the B of $M$. aragonensis that identifies the E4/E5 boundary [52] is found below the I-1 CIE at Site 1258 (Figure 2), whereas at other locations, including ODP Sites 1051 and 1263, Deep Sea Drilling Project (DSDP) Pacific Site 577 [19,41,42] and Possagno [19] this horizon lies above the I-2 CIE. Some uncertainty may lie in subtle differences between the identification of true $M$. aragonensis and its ancestor M. lensiformis [38]. We recognize M. aragonensis from $M$. lensiformis by its truly plano-convex test, truncated-cone shape, and rounded peripheral outline. In addition, we noted, according to [53] and [41,42] that, as visible in umbilical sides, typical M. aragonensis tests have 5.5 to 6 chambers in the last whorl instead of 4 to 4.5 chambers of $M$. lensiformis. However, considering that $M$. aragonensis has been distinguished similarly by all aforementioned authors, we conclude that the earliest appearance of this zonal marker is not related to taxonomical problems. Rather, this datum is diachronous by at least $100 \mathrm{kyr}$ (the time difference between I-1 and I-2; [2]), and that its true first appearance may have occurred slightly earlier at equatorial latitudes than at higher latitude areas.

Secondly, the T of M. subbotinae that marks the E5/E6 boundary [52] is recorded above the M CIE at Site 1258, just below the Q CIE at Site 1263, at the L1 event at Site 1051, below the P event in Tethyan sections and slightly above the J event at Site 577 (see Figure 3 in [42]). Clearly, this datum is highly diachronous and alternative foraminifera bioevent(s) are needed as substitutes in early Eocene planktic foraminiferal zonation schemes.

Thirdly, the B of A. cuneicamerata that marks the E6/E7a is found before the T of M. subbotinae. The same "reversal" of datums has been found across lower Eocene sections at Sites 1051, 1263 and Possagno [19,41,42,53]. Given the diachronicity of the B of A. cuneicamerata, [53] proposed the B of 
Astrorotalia (Planorotalites) palmerae as an alternative marker for the E6/E7a boundary, as this was supposedly synchronous with B of A. cuneicamerata at some sites [52,79].

Fourthly, the finding of B of Guembelitrioides nuttalli slightly above the K/X CIE at Site 1258 is problematic, as it should set the E7b/E8 boundary. However, the position of this datum is in good agreement with the record from the Tethyan Possagno section $[19,53]$ and bolsters observations at Site 1263, where it is recorded slightly above the Q CIE, and well below its putative first appearance. Luciani, et al. [53] noticed that, at Possagno, the abundance of G. nuttalli varied significantly, such that there is a Base of rare specimens $(\mathrm{Br},<1 \%)$ and a Base of common ( $\mathrm{Bc}, \sim 4 \%)$ specimens, where the latter coincides with the base of Zone E8. The Bc of G. nuttalli, which may be a proper bioevent, was not recorded at Site 1258, according to the evidence that the interval here studied do not encompass the middle Eocene.

Temporal offsets in early Eocene planktic foraminiferal occurrences are mostly realized only when detailed stratigraphy, such as through $\delta^{13} \mathrm{C}$ records, are coupled with detailed counting of specimens at multiple locations. The observed offsets clearly demonstrate the need of a revision of the Eocene planktic foraminiferal standard zonation, which is beyond the scope of this paper.

\subsection{The Planktic Foraminiferal Record across the EECO at Site 1258}

\subsubsection{Permanent Morozovella and Acarinina Switch in Abundances}

Our main result is that the relative abundance of the surface-dweller symbiont-bearing genus Morozovella, which dominated early Paleogene planktic foraminiferal assemblages from tropical-subtropical regions, markedly and permanently declined at the beginning of the EECO moving from mean percentage of $\sim 32 \%$ to less than $\sim 7 \%$. This distinct decrease in abundance occurred within $\sim 20 \mathrm{kyr}$ before a negative $\delta^{13} \mathrm{C}$ excursion known as the J event $(\sim 53.3 \mathrm{Ma})$, which marks the onset of the EECO. The permanent decrease of morozovellids is associated with reduction in species diversity, but an increase in the abundance of another symbiont-bearing foraminifera genus, Acarinina. The remarkable turnover from Morozovella to Acarinina was geographically widespread, as it is recorded at the start of the EECO in the subtropical Pacific (Site 577), and elsewhere in the subtropical Atlantic (Sites 1051 and 1263) [19,41,42]. Interestingly, the drop in abundance was asynchronous between sites. Actually, at the subtropical Site 1051 the morozovellids/acarininids switch occurred precisely at the J event [41] whereas at the temperate south Atlantic Site 1263 it occurred 165 kyr after the J event [42] Hence, our new data from Demerara Rise demonstrate that the morozovellid decline began first with unfavourable environmental conditions near the equatorial Atlantic Ocean and then extended to higher latitudes (Figure 6).

The triggering mechanism for the striking planktic foraminiferal turnover remains elusive, because both Morozovella and Acarinina existed in the mixed-layer. However, the two dominant genera, Morozovella and Acarinina, likely had different tolerances to temperature, ocean chemistry and possibly food supply. This would explain why anti-phase variations in their abundances occurred during several early Paleogene hyperthermals that happened before the EECO. This anti-phase relationship seems to derive from a competition within the same mixed-layer, where acarininids tolerate the atypical conditions better $[19,42,55,77,80]$. Unlike the early Eocene hyperthermal events, the prolonged EECO perturbation appears to have exceeded hostile conditions for morozovellids for a sufficiently long time, such that acarininids dominated surface water habitats afterward. It is notable that the delay between the morozovellid crash at the equator and the high latitude site is slightly longer ( $185 \mathrm{kyr}$ ) than the typical early Eocene hyperthermal duration.

Interestingly, most Morozovella species usually exhibit less high $\delta^{13} \mathrm{C}$ and low $\delta^{18} \mathrm{O}$ values with respect to most acarininids. This feature has been found in examinations of the stable isotopic composition of late Paleocene and Eocene foraminiferal assemblages [41,64,71,72,81-83]. Most morozovellids may have thus lived slightly deeper in the mixed-layer habitat or they may have sunk there at gametogenesis, as is further supported by the occurrence of a late stage crust in the test and 
by the isotope values. These features are especially evident in M. aragonensis, M. lensiformis [71,72]) and possibly in $M$. aequa and M. subbotinae [41,64]. Changes in the vertical temperature or $\mathrm{pH}$ profile leading to more intense changes in the middle-lower mixed-layer with respect to the upper mixed-layer may have affected morozovellid reproduction at depth and reduced their abundance. However, periodic increases in temperature and declines in $\mathrm{pH}$ and omega-calcite occurred during the pre-EECO hyperthermals as well. It is unclear whether conditions were simply more severe during the EECO and whether changes in temperature or carbonate chemistry were more significant in driving the permanent morozovellid crash. The evidence that the morozovellid crisis began at the equatorial Atlantic Ocean is unexpected. Actually, if carbonate chemistry were the primary driver, we would expect earlier, more severe changes at the high latitudes, where omega-calcite is already relatively lower.

Changes in food supply could be a critical cause to explain the morozovellid/acarininid changes at the EECO. Change in nutrient availability have been taken in account to explain the switch in abundance between Morozovella and Acarinina during the PETM, ETM2 and K/X events, when Acarinina became dominant over Morozovella in a number of Tethyan successions. This has been interpreted as signifying enhanced eutrophication of surface waters near continental margins [55,77,80,84-87], an idea consistent with evidence for elevated (albeit more seasonal) riverine discharge during these hyperthermals [88-92]. Enhanced eutrophication may have been detrimental for morozovellids, presumed to be a more oligotrophic group than acarininids. Increased nutrient availability is also validated in the Tethyan area by the relatively high concentration of radiolarians which may reflect eutrophication [93] and that is recorded also at the start of the EECO from the Possagno section [19]. Actually, at Site 1051 increased nutrient availability can be testified by the radiolarians percentage that markedly increases within the EECO [41]. Nevertheless, there is no evidence of increased eutrophication at the other sites documenting the permanent morozovellid decline, included Site 1258.

Our results clearly highlight the need for further investigation in order to constrain possible environmental causes of the observed biotic changes.
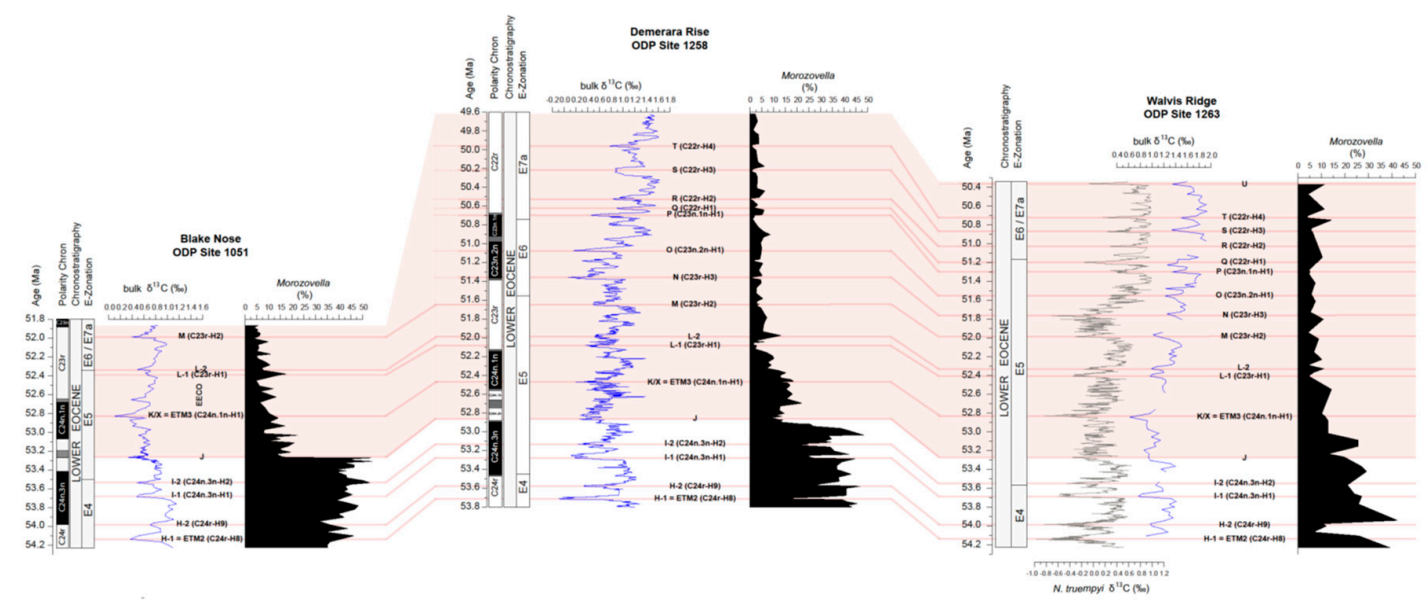

Figure 6. Early Eocene $\delta^{13} \mathrm{C}$ and relative abundance of genus Morozovella plotted versus Age (Ma) from Atlantic sites 1051, 1258 and 1263. Note that the permanent decline in abundance occurred earlier at Site 1268 ( 20 kyr before the J CIE) and then extended at Site 1051 where it occurred exactly at the J event [41] and finally at Site 1263, where this permanent drop in abundance is recorded $165 \mathrm{kyr}$ above the J event [42].

\subsubsection{Changes in Morozovellid Species Population and Test Size}

The relative abundance of different morozovellid species at Site 1258 (Figure 4) shows that M. subbotinae and M. crater are the most important component of morozovellids population below the EECO, followed by M. marginodentata and $M$. gracilis. Changes in these species are mainly responsible for the morozovellid decline in abundance. 
The behaviour of the different Morozovella species varies across the hyperthermals in terms of changes in abundance. Reduction in total morozovellid abundance across most CIEs below the EECO is due to the transient drop of M. subbotinae, M. gracilis, M. marginodentata and M. lensiformis whereas M. formosa, M. crater and M. aragonensis temporarily increase. In particular, M. formosa peaks in abundance at the H2 CIE. Therefore, different morozovellid species had diverse tolerance to the environmental stressors induced by the hyperthermals.

Figure 5 compares the relative abundance of morozovellid species plotted against age (Ma) from Site 1258, Site 1051 and Site 1263. Data from Site 1051 come from [41] and are shown in Table S4. The greater total abundance of morozovellids at Sites 1051 and 1258 can be explained by the low latitude of these two sites with respect to Site 1263 considering that morozovellids are known warm water indices $[62,63,82]$. Our data show that the various Morozovella species are differently distributed across the sites investigated. The species that display the most evident variations in abundance between sites are: M. marginodentata, M. gracilis, M. subbotinae, M. aragonensis, $M$. crater and M. aequa. Prior to the EECO, the first five of these species show greater abundance at the equatorial Site 1258 and subtropical Site 1051, indicating that their biogeographic optimum was at low latitudes. The evidence that the zonal marker $M$. aragonensis first appears at the equatorial site confirms the warm-water preference of this species and could somewhat explaining the documented diachronism of its base across several sites. Conversely, Morozovella aequa is demonstrated to have preferred temperate latitudes as it shows highest relative abundance at Site 1263. The remaining species are relatively less abundant in all the sites.

The morozovellid crisis involved the species M. aequa, M. marginodentata, M. gracilis, M. subbotinae at all three sites, which demonstrates that the environmental stressors responsible for their decline involved the same species independent of their relative abundance. The species $M$. crater contributed to the morozovellid crash only at the low latitude sites 1258 and 1051. M. formosa and M. lensiformis only showed a permanent decline in abundance at Site 1258. Significantly, those species experiencing the morozovellid crash decline firstly at the Atlantic Equatorial Site 1258 where the abundance of M. aequa, M. subbotinae, M. gracilis, M. marginodentata, M. formosa, M. lensiformis and M. crater permanently decline $\sim 20 \mathrm{kyr}$ before the J event (Figure 5). The same species with the exception of $M$. formosa and M. lensiformis drop in abundance at Site 1051 exactly at the J event [41] whereas M. aequa, M. subbotinae, M. gracilis and M. marginodentata decline in abundance at the temperate south Atlantic Site 1263 $\sim 165 \mathrm{kyr}$ after the J event. As mentioned above, M. lensiformis and M. crater do not suffer a decline in abundance at the temperate Site 1263. These records underline the complexity of the permanent drop in abundance of genus Morozovella at the EECO; each species, though belonging to the same genus, played a different role during the crisis. Possibly, M. formosa, $M$. lensiformis and $M$. crater were able to migrate or to persist to survive at higher latitudes where environmental conditions were less extreme.

The various morozovellid species also display some dissimilarity in their response to hyperthermals. Specifically, the species that that decline permanently and that became extinct within the EECO generally show a decrease in abundance across the largest CIEs. Two exceptions are $M$. formosa and $M$. crater that record peaks in abundance from Site 1258 at the ETM2, H2, I1 CIEs and a minor increase in abundance at the L2 CIE. M. aragonensis, which is not present at the base of the succession at Site 1258, displays peaks in abundance across the hyperthermals. The fact that most of the morozovellids decrease across the hyperthermals temporarily and then decline permanently at the EECO suggests similar adverse environmental conditions, but it also suggests that it was the duration of environmental change during EECO that crossed the resilience threshold. Given that it is however unclear that absolute environmental conditions deteriorated to a greater degree during the EECO compared to during individual hyperthermal events of the early Eocene.

Interestingly, the size of morozovellids shows significant changes across the interval investigated (Table 1). Specifically, at Site 1258, the mean percentage of fraction $>300 \mu \mathrm{m}$ displays a reduction when comparing the interval below and above the J CIE ( $29 \%$ vs $~ 21 \%)$. In particular, this reduction in maximum test size involves principally the species Morozovella gracilis, M. marginodentata, M. subbotinae, 
M. formosa and M. crater that were present in the $>300 \mu \mathrm{m}$ fraction below the J CIE but the results absent (Morozovella gracilis, M. marginodentata) or extremely rare from this major fraction above the J CIE. The test size reduction does not involve the species $M$. aragonensis that ranges up to the middle Eocene [52]. We did not include the sample from $77.8 \mathrm{rmcd}$ in the test size calculation because the dominant species (M. aragonensis) and the species $M$. caucasica are predominantly of large size. These results may indicate that the species $M$. subbotinae, M. gracilis, M. marginodentata, M. formosa and $M$. crater that mainly account for the morozovellid decline underwent a size reduction following their decline in abundance. The fraction 250-300 $\mu \mathrm{m}$ accounts for the aforementioned morozovellid test-size reduction because it markedly increases above the EECO base; it moves from a mean percentage of $\sim 21 \%$ to $\sim 58 \%$. The species M. aequa and M. lensiformis are very rare above the J CIE, which makes it difficult to assess their size changes using the method here adopted. Interestingly, the species M. marginodentata, M. gracilis and $M$. formosa also show a test size reduction at the Atlantic Site 1051 [41].

An extremely high percentage of morozovellid specimens from the $200-250 \mu \mathrm{m}$ fraction is recorded in samples from $112.37 \mathrm{rmcd}$ and $107.27 \mathrm{rmcd}$ that give values of $76.4 \%$ and $68.9 \%$, respectively. In the same samples the percentage of the $>300 \mu \mathrm{m}$ fraction drops to $4.1 \%$ and $9.5 \%$. This marked reduction in morozovellids test size involves all the species occurring in these samples. Significantly, the sample from $112.37 \mathrm{rmcd}$ is placed slightly above the I1 CIE and the sample from $107.27 \mathrm{rmcd}$ is at the J1 event, suggesting adverse environmental conditions are associated with declining test size.

Several potential stressors may explain both the reduced size and the permanent morozovellid decline. These include algal photosymbiont inhibition (bleaching), increase in temperature, decrease in oxygen levels and decrease in $\mathrm{pH}$ and/or calcite saturation state [94,95]. A bleaching hypothesis has been tested at the northwest Atlantic Site 1051 by measuring stable isotopes of different size fractions of multiple planktic foraminiferal genera and species [41]. The results demonstrate that morozovellids indeed reduced their algal-symbiont relationships just after their abundance reduction at the EECO onset, but this was a transitory effect. Moreover, evidence for bleaching also occurred in the acarininids, but their relative abundance increased. Possible bleaching episodes may explain the general and marked test-size reduction of morozovellids at Site 1258 as related to the I1 and J events though carbon stable isotope data from different size fractions is necessary to confirm.

Some of the various possible stressors are linked. For instance, a temperature increase within the mixed-layer drives a decrease in oxygen solubility that could cause morozovellid test-size reduction because demand for oxygen and nutrients increases with temperature in protists due to accelerating metabolism [72]. Thus, a strategy to optimize resource uptake is to enlarge surface area/volume ratio by reducing the cell mass and therefore the test-size [96].

Changes in ocean carbonate chemistry also may have affected morozovellid calcification and contributed to the observed test size reduction. Recent culturing and open ocean observations suggest that that omega-calcite saturation state can affect variably sized foraminifera differently, such that larger planktic foraminifera preferentially reduce their calcification [97]. We cannot exclude that morozovellids may have decreased their maximum size as a consequence of drops in saturation state and $\mathrm{pH}$, because there are several short-term negative CIEs within the EECO probably signifying addition of $\mathrm{CO}_{2}$ to the ocean and atmosphere [20,98]. However, the extended duration of EECO warmth should have led to enhanced weathering and kept saturation state high despite the impact of high atmospheric $\mathrm{CO}_{2}$ on surface ocean $\mathrm{pH}$.

At Site 1263 the morozovellid test-size records less marked changes with respect to the low-latitude sites. This suggests temperature, rather than saturation state, is a primary driver of trends in test size, since high latitude sites already have lower saturation state with respect to equatorial latitudes. Significantly, at Site 1263 M. aequa declines in abundance but does not reduce its size and shows a longer stratigraphic range with respect to the equatorial site, suggesting that environmental conditions at this temperate site were less extreme for this species.

The other species occurring within the $>300 \mu \mathrm{m}$ fraction at Site 1263 are mainly $M$. crater and M. lensiformis and they show a reduction in abundance at EECO. The species M. gracilis, M. marginodentata 
and M. subbotinae do show a reduction in abundance at the EECO, and these are only present in the $>300 \mu \mathrm{m}$ and 250-300 $\mu \mathrm{m}$ fractions stratigraphically below this decline, thus confirming their test-size decrease within the EECO. The evidence for a less pronounced decrease in test size at Site 1263 is potentially related to the fact that the morozovellid crisis in abundance is less extreme at this site with respect to the low latitude Atlantic sites.

\subsubsection{Chiloguembelinid Virtual Disappearance at the EECO}

The small-sized, thin-walled planktic foraminiferal chiloguembelinids bearing a biserial disposition of the chambers constitute a minor component of the assemblages at the equatorial Site 1258 . This is in line with the evidence that this group proliferates at high latitude (e.g., [99]). However, their virtual disappearance $\sim 160 \mathrm{kyr}$ before the K/X event is significant because this group becomes virtually absent also in the subtropical and temperate Atlantic Sites 1051 and 1263 at the beginning of the EECO slightly before (Site 1051) or at the K/X event (1263) [64]. This striking widespread decline through the Atlantic Ocean implies marked paleoceanographic changes. Recent analyses by [64] demonstrate the early Eocene Chiloguembelina occupied a thermocline niche, compatible with that of the Oxygen Minimum Zone (OMZ), throughout the Atlantic Ocean as demonstrated by a stable isotope signature close to the deep-dweller Subbotina and benthic foraminifera. These authors hypothesize that intermediate water temperatures probably rose significantly during the EECO, thus becoming too warm for this genus. In addition, elevated ocean temperatures could have enhanced the rate of bacterial respiration and remineralisation significantly, thus resulting in more efficient recycling of nutrients higher in the water column $[71,72,100]$. This would have resulted in a restriction of food supply at depth and subsequently cut out the deeper dwelling niche of chiloguembelinids. Therefore, chiloguembelinids, considered as a eutrophic indicator, may have suffered of reduced food supply besides the warmer temperatures. Interestingly, recently published foraminiferal-bound nitrogen isotope data demonstrate that the extent of water column denitrification, a process that is known to occur only in oxygen depleted waters in the present-day Ocean, and that is inferred by FB (Foraminiferal Bound)- $\delta^{15} \mathrm{~N}$ values, started to markedly decline within the EECO at 53 Ma ago [101]. This indicates enhanced oxygenation at the OMZ during the EECO. A combination of the increased temperature and oxygenation of the thermocline might have played a major role in driving the disappearance of chiloguembelinids inhabiting the OMZ [64].

\section{Conclusions}

Here we present new data on the planktic foraminiferal response to the Early Eocene Climatic Optimum (EECO, 54-48 Ma) from the western equatorial Atlantic ODP Site 1258 (Demerara Rise) and South Atlantic Site 1263. Our results reveal significant modifications within planktic foraminiferal assemblages that are compared with changes recorded from Atlantic Site 1051, thus implying widespread paleoceanographic changes. The main results are summarized below.

Our results highlight pronounced changes within low-latitude planktic foraminiferal abundances across the EECO (Figure 3). The most striking variation happened near the J CIE: a permanent decline in morozovellid abundance paralleled a long-term rise in acarininid abundance. Examining the abundances and test sizes of various morozovellid species over time at three sites located at well-separated latitudes from the Atlantic Ocean (Figures 4 and 5), allows us to further understand this remarkable switch in zooplankton. Another important modification within planktic foraminiferal assemblages involves the genus Chiloguembelina that become virtually absent from $\mathrm{K} / \mathrm{X} \mathrm{CIE}$, as also recorded in the aforementioned Atlantic sites thus implying significant paleoceanographic modifications.

1 Our biostratigraphic results require a revision of the standard zonal scheme by [52] because the zonal marker of Zones E5, E6 and E7a are revealed to be diachronous, confirming results from previous papers. The earliest appearance at Site 1258 of Morozovella aragonensis, which marks the base of Zone E5, probably represents the first appearance datum of this species that successively appears to have 
migrated at higher latitude. Its greater abundance at the equatorial Site 1258 reveals a warmer-water preference of this species.

2 The relative abundance of the genus Morozovella that dominated early Paleogene tropical-subtropical planktic foraminiferal assemblages, markedly and permanently declined at the beginning of the EECO moving from mean percentage of $\sim 32 \%$ to less than $\sim 7 \%$. The distinct decrease in Morozovella abundance occurred at Site 1258 within $~ 20$ kyr before a negative $\delta^{13} \mathrm{C}$ excursion known as the J event $(\sim 53.3 \mathrm{Ma})$, which marks the beginning of the EECO. This remarkable decline was geographically widespread as it is recorded at the start of the EECO in the subtropical Pacific (Site 577), subtropical and temperate Atlantic (sites 1051 and 1263) and Tethyan region (Possagno section, northern Italy). The permanent decrease of morozovellids is associated with a reduction in species diversity, but an increase in the abundance of another symbiont-bearing foraminifera genus, Acarinina. Interestingly, the timing of the drop in abundance is close but different at each site. Actually, at the subtropical Site 1051 the morozovellids/acarininids switch occurred precisely at the J event [41] whereas at the temperate south Atlantic Site 1263 it occurred $165 \mathrm{kyr}$ after the J event [42]. Our new data from Site 1258 demonstrate therefore that the morozovellid decline began first with unfavourable environmental conditions near the equatorial Atlantic Ocean and then extended to higher latitudes.

The triggering mechanism for the striking planktic foraminiferal turnover remains elusive, because both Morozovella and Acarinina existed in the mixed-layer. However, the two dominant genera, Morozovella and Acarinina, likely had different tolerances to temperature and ocean chemistry. This would explain why anti-phase variations in their abundances occurred during several early Paleogene hyperthermals that happened before the EECO. Seemingly, it derives from a competition within the same mixed-layer, where acarininids tolerate the atypical conditions better. The long-lasting environmental conditions at the EECO exceeded the threshold resilience of morozovellids thus permitting acarininids to dominate the mixed-layer habitat afterwards.

3 The relative abundance changes of the different Morozovella species from Site 1258 as compared with the species abundance from the Atlantic Sites 1051 and 1263 reveal that morozovellid species are differently distributed. This allows us to outline the early Eocene biogeographic distribution across the Atlantic Ocean. The diverse morozovellid species also display dissimilarity responses to short-term fluctuations, e.g., across the hyperthermals. Specifically, the species that decline in abundance permanently and that became extinct within the EECO generally show a decrease in abundance across the main CIEs. The fact that most morozovellids decrease temporarily in abundance across the hyperthermals and then decline permanently at the EECO suggests similar adverse environmental conditions are responsible for the decline, but further suggests that the long-lasting conditions reached at the EECO led to the crossing of a resilience threshold.

4 We record a test size reduction for the species that contributed to the morozovellid crisis. Several potential stressors may explain the recorded size reduction. They may include: algal photosymbiont inhibition (bleaching), increases in temperature, decreases in oxygen levels and decreases in $\mathrm{pH}$ and/or saturation state. Interestingly, the hyperthermals I1 and J1 record a marked morozovellid test-size reduction because morozovellids are mainly present in the $<200 \mu \mathrm{m}$ fraction. Possible bleaching episodes may explain the general and marked test size reduction of morozovellids at Site 1258 though a confirmation would be necessary from the carbon stable isotope signature at different sizes.

5 The small-sized, thin-walled planktic foraminiferal chiloguembelinids bearing a biserial disposition of the chambers constitute a minor component of the assemblages at the Atlantic Site 1258 . However, their virtual disappearance $\sim 160 \mathrm{kyr}$ before the $\mathrm{K} / \mathrm{X}$ event is significant because this group became virtually absent in the subtropical and temperate Atlantic Sites 1051 and 1263 at the beginning of the EECO either slightly before (Site 1051) or at the K/X event (1263) [64]. Recently published foraminiferal-bound nitrogen isotope data suggest enhanced oxygenation of the thermocline in the early EECO [101]. A combination of increased temperature effect and oxygenation of the thermocline might have played a major role in driving the disappearance of chiloguembelinids inhabiting the OMZ [64]. 
Supplementary Materials: The following are available online at http://www.mdpi.com/2076-3263/10/3/88/s1, Table S1: Planktic foraminiferal abundance and F-index at Site 1258, Table S2: Morozovella species abundance at Site 1258, Table S3: Morozovella species abundance at Site 1263, Table S4: Morozovella species abundance at Site 1051.

Author Contributions: R.D. and V.L. provided the conceptualization, microscope investigation, visualization and writing the original draft and funding acquisition. G.R.D., B.S.W. and S.K.T. provided writing review and editing, and supervision. S.K.T. made available the same samples from the paper Kirtland-Turner et al. (2014). All authors have read and agreed to the published version of the manuscript.

Funding: This research was funded by MIUR-PRIN 2017 “Biotic Resilience to Global Change”, to V. LUCIANI (within a National Research Project coordinated by E. Erba, Milan University, Italy), grant number 80007370382 and FAR (Fondo Ateneo Ricerca, Ferrara University) 2019 to V.L.

Acknowledgments: We thank the Bremen Core Repository for handling our sample request. We are grateful to the Editor and three anonymous reviewers who gave suggestions that improving the paper.

Conflicts of Interest: The authors declare no conflict of interest. The funders had no role in the design of the study; in the collection, analyses, or interpretation of data; in the writing of the manuscript, or in the decision to publish the results.

\section{Nomenclature: List of Species Cited in Text and Figures}

Astrorotalia palmerae (Cushman and Bermudez, 1937)

Catapsydrax unicavus Bolli, Loeblich and Tappan, 1957

Globanomalina ovalis Haque, 1956

Globanomalina planoconica (Subbotina, 1953)

Guembelitrioides nuttalli (Hamilton, 1953)

Morozovella aequa (Cushman and Renz, 1942)

Morozovella aragonensis (Nuttall, 1930)

Morozovella caucasica (Glaessner, 1937)

Morozovella crater (Hornibrook, 1958)

Morozovella formosa (Bolli, 1957)

Morozovella gracilis (Bolli, 1957)

Morozovella lensiformis (Subbotina, 1953)

Morozovella marginodentata (Subbotina, 1953)

Morozovella subbotinae (Morozova, 1939)

Praemurica lozanoi (Colom, 1954)

Pseudoglobigerinella bolivariana (Petters, 1954)

Subbotina senni (Beckmann, 1953)

\section{References}

1. Zachos, J.C.; Dickens, G.R.; Zeebe, R.E. An early Cenozoic perspective on greenhouse warming and carbon-cycle dynamics. Nature 2008, 451, 279-283. [CrossRef] [PubMed]

2. Westerhold, T.; Röhl, U.; Donner, B.; Zachos, J.C. Global Extent of Early Eocene Hyperthermal Events: A New Pacific Benthic Foraminiferal Isotope Record from Shatsky Rise (ODP Site 1209). Paleoceanogr. Paleoclimatol. 2018, 33. [CrossRef]

3. Hollis, C.J.; Dunkley Jones, T.; Anagnostou, E.; Bijl, P.K.; Cramwinckel, M.J.; Cui, Y.; Dickens, G.R.; Edgar, K.M.; Eley, Y.; Evans, D.; et al. The DeepMIP contribution to PMIP4: Methodologies for selection, compilation and analysis of latest Paleocene and early Eocene climate proxy data, incorporating version 0.1 of the DeepMIP database. Geosci. Model Dev. 2019, 12, 3149-3206. [CrossRef]

4. Bijl, P.K.; Schouten, S.; Sluijs, A.; Reichart, G.-J.; Zachos, J.C.; Brinkhuis, H. Early Paleogene temperature evolution of the southwest Pacific Ocean. Nature 2009, 461, 776-779. [CrossRef] [PubMed]

5. Huber, M.; Caballero, R. The early Eocene equable climate problem revisited. Clim. Past 2011, 7, $603-633$. [CrossRef]

6. Hollis, C.J.; Taylor, K.W.R.; Handley, L.; Pancost, R.D.; Huber, M.; Creech, J.B.; Hines, B.R.; Crouch, E.M.; Morgans, H.E.G.; Crampton, J.S.; et al. Early Paleogene temperature history of the Southwest Pacific Ocean: Reconciling proxies and models. Earth Planet. Sci. Lett. 2012, 349, 53-66. [CrossRef] 
7. Pross, J.; Contreras, L.; Bijl, P.K.; Greenwood, D.R.; Bohaty, S.M.; Schouten, S.; Bendle, J.A.; Röhl, U.; Tauxe, L.; Raine, J.I.; et al. Persistent near-tropical warmth on the Antarctic continent during the early Eocene Epoch. Nature 2012, 488, 73-77. [CrossRef]

8. Inglis, G.N.; Farnsworth, A.; Lunt, D.; Foster, G.L.; Hollis, C.J.; Pagani, M.; Jardine, P.E.; Pearson, P.N.; Markwick, P.; Galsworthy, A.M.J.; et al. Descent toward the icehouse: Eocene sea surface cooling inferred from GDGT distributions. Paleoceanography 2015, 30, 100-1020. [CrossRef]

9. Kennett, J.P.; Stott, L.D. Abrupt deep-sea warming; palaeoceanographic changes and benthic extinctions at the end of the Palaeocene. Nature 1991, 353, 225-229. [CrossRef]

10. Thomas, E.; Zachos, J.C.; Bralower, T.J. Deep-sea environments on a warm Earth: Latest Paleocene-early Eocene. In Warm Climates in Earth History; Huber, B., MacLeod, K., Wing, S., Eds.; Cambridge University Press: Cambridge, UK, 2000; pp. 132-160.

11. Lourens, L.J.; Sluijs, A.; Kroon, D.; Zachos, J.C.; Thomas, E.; Röhl, U.; Bowles, J.; Raffi, I. Astronomical pacing of late Palaeocene to early Eocene global warming events. Nature 2005, 435, 1083-1087. [CrossRef]

12. Nicolo, M.J.; Dickens, G.R.; Hollis, C.J.; Zachos, J.C. Multiple early Eocene hyperthermals: Their sedimentary expression on the New Zealand continental margin and in the deep sea. Geology 2007, 35, 99-702. [CrossRef]

13. Zachos, J.C.; McCarren, H.K.; Murphy, B.; Röhl, U.; Westerhold, T. Tempo and scale of late Paleocene and early Eocene carbon isotope cycles: Implications for the origin of hyperthermals. Earth Planet. Sci. Lett. 2010, 299, 242-249. [CrossRef]

14. Coccioni, R.; Bancalà, G.; Catanzariti, R.; Fornaciari, E.; Frontalini, F.; Giusberti, L.; Jovane, L.; Luciani, V.; Savian, J.; Sprovieri, M. An integrated stratigraphic record of the Palaeocene-lower Eocene at Gubbio (Italy), new insights into the early Palaeogene hyperthermals and carbon isotope excursions. Terra Nova 2012, 24, 380-386. [CrossRef]

15. Kirtland-Turner, S.; Sexton, P.F.; Charled, C.D.; Norris, R.D. Persistence of carbon release events through the peak of early Eocene global warmth. Nat. Geosci. 2014, 7, 748-751. [CrossRef]

16. Littler, K.; Röhl, U.; Westerhold, T.; Zachos, J.C. A high-resolution benthic stable isotope record for the South Atlantic: Implications for orbital-scale changes in late Paleocene-early Eocene climate and carbon cycling. Earth Planet. Sci. Lett. 2014, 401, 18-30. [CrossRef]

17. Slotnick, B.S.; Dickens, G.R.; Hollis, C.J.; Crampton, J.S.; Strong, P.S.; Phillips, A. The onset of the Early Eocene climatic optimum at branch stream, Clarence River Valley. N. Z. J. Geol. Geophys. 2015, 58. [CrossRef]

18. Lauretano, V.; Hilgen, F.J.; Zachos, J.C.; Lourens, L.J. Astronomically tuned age model for the early Eocene carbon isotope events: A new high-resolution $\delta^{13} \mathrm{C}$ benthic record of ODP Site 1263 between $\sim 49$ and $\sim 54$ Ma. Newsl. Stratigr. 2016, 49, 383-400. [CrossRef]

19. Luciani, V.; Dickens, G.R.; Backman, J.; Fornaciari, E.; Giusberti, L.; Agnini, C.; D'Onofrio, R. Major perturbations in the global carbon cycle and photosymbiont-bearing planktic foraminifera during the early Eocene. Clim. Past 2016, 12, 981-1007. [CrossRef]

20. Dickens, G.R.; Castillo, M.; Walker, J.C.G. A blast of gas in the latest Paleocene: Simulating first-order effects of massive dissociation of oceanic methane hydrate. Geology 1997, 25, 259-262. [CrossRef]

21. Pagani, M.; Caldeira, K.; Archer, D.; Zachos, J.C. An ancient carbon mystery. Science 2006, 314, $1556-1557$. [CrossRef]

22. McInerney, F.A.; Wing, S.L. The Paleocene-Eocene Thermal Maximum: A perturbation of carbon cycle, climate, and biosphere with implications for the future. Annu. Rev. Earth Planet. Sci. 2011, 39, 489-516. [CrossRef]

23. Zeebe, R.E.; Zachos, J.C. Long-term legacy of massive carbon input to the Earth system: Anthropocene versus Eocene. Philos. Trans. R. Soc. A 2013, 371. [CrossRef] [PubMed]

24. Wing, S.L.; Bown, T.M.; Obradovich, J.D. Early Eocene biotic and climatic change in interior western North America. Geology 1991, 19, 1189-1192. [CrossRef]

25. Zonneveld, J.P.; Gunnell, G.F.; Bartels, W.S. Early Eocene fossil vertebrates from the southwestern Green River Basin, Lincoln and Uinta Counties, Wyoming. J. Vertebr. Paleontol. 2000, 20, 369-386. [CrossRef]

26. Wilf, P.; Cúneo, R.N.; Johnson, K.R.; Hicks, J.F.; Wing, S.L.; Obradovich, J.D. High plant diversity in Eocene South America: Evidence from Patagonia. Science 2003, 300, 122-125. [CrossRef]

27. Falkowski, P.G.; Katz, M.E.; Milligan, A.J.; Fennel, K.; Cramer, B.S.; Aubry, M.P.; Berner, R.A.; Novacek, M.J.; Zapol, W.M. Mammals evolved, radiated, and grew in size as the concentration of oxygen in Earth's atmosphere increased during the past 100 million years. Science 2005, 309, 2202-2204. [CrossRef] 
28. Agnini, C.; Muttoni, G.; Kent, D.V.; Rio, D. Eocene biostratigraphy and magnetic stratigraphy from Possagno, Italy: The calcareous nannofossils response to climate variability. Earth Planet. Sci. Lett. 2006, 241, 815-830. [CrossRef]

29. Agnini, C.; Fornaciari, E.; Raffi, I.; Catanzariti, R.; Pälike, H.; Backman, J.; Rio, D. Biozonation and biochronology of Paleogene calcareous nannofossils from low to middle latitudes. Newsl. Strat. 2014, 47, 131-181. [CrossRef]

30. Sims, P.A.; Mann, D.G.; Medlin, L.K. Evolution of the diatoms: Insights from fossil, biological and molecular data. Phycologia 2006, 45, 361-402. [CrossRef]

31. Woodburne, M.O.; Gunnell, G.F.; Stucky, R.K. Climate directly influences Eocene mammal faunal dynamics in North America. Proc. Natl. Acad. Sci. USA 2009, 106, 13399-13403. [CrossRef]

32. Schneider, L.J.; Bralower, T.J.; Kump, L.J. Response of nannoplankton to early Eocene ocean destratification. Palaeogeogr. Paleoeclimatol. Palaeoecol. 2011, 310, 152-162. [CrossRef]

33. Shamrock, J.L.; Watkins, D.K.; Johnston, K.W. Eocene biogeochronology of ODP Leg 122 Hole 762C, Exmouth Plateau (northwest Australian Shelf). Stratigraphy 2012, 9, 55-76.

34. Oreshkina, T.V. Evidence of late Paleocene-Early Eocene hyperthermal events in biosiliceous sediments of Western Siberia and adjacent areas. Aust. J. Earth Sci. 2012, 105, 145-153.

35. Figueirido, B.; Janis, C.M.; Pérez-Claros, J.A.; De Renzi, M.; Palmqvist, P. Cenozoic climate change influences mammalian evolutionary dynamics. Proc. Natl. Acad. Sci. USA 2012, 109, 722-727. [CrossRef] [PubMed]

36. Norris, R.D. Biased extinction and evolutionary trends. Paleobiology 1991, 17, 388-399. [CrossRef]

37. Berggren, W.A.; Pearson, P.N.; Huber, B.T.; Wade, B.S. Taxonomy, biostratigraphy and phylogeny of Eocene Acarinina. In Atlas of Eocene Planktonic Foraminifera; Pearson, P.N., Olsson, R.K., Huber, B.T., Hemleben, C., Berggren, W.A., Eds.; Cushman Found. Special Publication for Foraminiferal Res.: Greenville, NC, USA, 2006; Volume 41, pp. 257-326.

38. Pearson, P.N.; Olsson, R.K.; Hemblen, C.; Huber, B.T.; Berggren, W.A.; Pearson, P.N. Atlas of Eocene Planktonic Foraminifera; Pearson, P.N., Olsson, R.K., Hemblen, C., Huber, B.T., Berggren, W.A., Eds.; Cushman Found. Special Publication for Foraminiferal Res.: Greenville, NC, USA, 2006; Volume 41, p. 513.

39. Aze, T.; Ezard, T.H.G.; Purvis, A.; Coxall, H.K.; Stewart, D.R.M.; Wade, B.S.; Pearson, P.N. A phylogeny of Cenozoic macroperforate planktonic foraminifera from fossil data. Biol. Rev. 2011, 86, 900-927. [CrossRef]

40. Fraass, A.J.; Kelly, D.K.; Peters, S.E. Macroevolutionary history of the planktic foraminifera. Annu. Rev. Earth Planet. Sci. 2015, 43, 139-166. [CrossRef]

41. Luciani, V.; D'Onofrio, R.; Dickens, G.R.; Wade, B.S. Did photosymbiont bleaching lead to the demise of planktic foraminifer Morozovella at the Early Eocene Climatic Optimum? Paleoceanography 2017, 32, 1115-1136. [CrossRef]

42. Luciani, V.; D'Onofrio, R.; Dickens, G.R.; Wade, B.S. Planktic foraminiferal response to early Eocene carbon cycle perturbations in the southeast Atlantic Ocean (ODP site 1263). Glob. Planet. Chang. 2017, 158, 119-133. [CrossRef]

43. Frontalini, F.; Coccioni, R.; Catanzariti, R.; Jovane, L.; Savian, J.F.; Sprovieri, M. The Eocene Thermal Maximum 3: Reading the environmental perturbations at Gubbio (Italy). In The Stratigraphic Record of Gubbio: Integrated Stratigraphy of the Late Cretaceous-Paleogene Umbria-Marche Pelagic Basin; Menichetti, M., Coccioni, R., Montanari, A., Eds.; Geological Society of America Special Papers: Boulder, Colorado, USA, 2016; Volume 524, pp. 161-326.

44. Shipboard Scientific Party: Site 1258. In Proceedings of the Ocean Drilling Program, Init. Repts., /207; Erbacher, J.; Mosher, D.C.; Malone, M.J. (Eds.) Ocean Drilling Program: College Station, TX, USA; pp. 1-117. [CrossRef]

45. Van Hinsbergen, D.J.J.; de Groot, L.V.; van Schaik, S.J.; Spakman, W.; Bijl, P.K.; Sluijs, A.; Langereis, C.G.; Brinkhuis, H. A paleolatitude calculator for paleoclimate studies. PLoS ONE 2015, 10, e0126946. [CrossRef] [PubMed]

46. Sexton, P.F.; Wilson, P.A.; Pearson, P.N. Microstructural and geochemical perspectives on planktic foraminiferal preservation: 'Glassy' versus 'Frosty'. Geochem. Geophys. Geosyst. 2006, 7. [CrossRef]

47. Martini, E. Standard Tertiary and Quaternary calcareous nannoplankton zonation. In Proceedings of the 2nd Planktonic Conference, Rome, Italy, 1970; Farinacci, A., Ed.; Tecnoscienza: Rome, Italy, 1971; Volume 2, pp. 739-785. 
48. Berggren, W.A.; Kent, D.V.; Swisher, C.C., III; Aubry, M.-P. A revised Cenozoic geochronology and chronostratigraphy. In Geochronology, Time Scales and Global Stratigraphic Correlation; Berggren, W.A., Kent, D.V., Aubry, M.P., Hardenbol, J., Eds.; SEPM Society for Sedimentary Geology Special Publication: Tysons, VA, USA, 1995; Volume 54, pp. 129-212. [CrossRef]

49. Westerhold, T.; Röhl, U.; Frederichs, T.; Agnini, C.; Raffi, I.; Zachos, J.C.; Wilkens, R.H. Astronomical calibration of the Ypresian timescale: Implications for seafloor spreading rates and the chaotic behaviour of the solar system? Clim. Past 2017, 13, 1129-1152. [CrossRef]

50. Westerhold, T.; Röhl, U.; Laskar, J. Time scale controversy: Accurate orbital calibration of the early Paleogene. Geochem. Geophys. Geosyst. 2012, 13. [CrossRef]

51. Laskar, J.; Fienga, A.; Gastineau, M.; Manche, H. La2010: A new orbital solution for the long term motion of the Earth. Astron. Astrophys. 2011, 532. [CrossRef]

52. Wade, B.S.; Pearson, P.N.; Berggren, W.A.; Pälike, H. Review and revision of Cenozoic tropical planktonic foraminiferal biostratigraphy and calibration to the geomagnetic polarity and astronomical time scale. Earth Sci. Rev. 2011, 104, 111-142. [CrossRef]

53. Luciani, V.; Giusberti, L. Reassessment of the early-middle Eocene planktic foraminiferal biomagnetochronology: New evidence from the Tethyan Possagno section (NE Italy) and Western North Atlantic Ocean ODP Site 1051. J. Foraminifer. Res. 2014, 44, 187-201. [CrossRef]

54. Zachos, J.C.; Röhl, U.; Schellenberg, S.A.; Sluijs, A.; Hodell, D.A.; Kelly, D.C.; Thomas, E.; Nicolo, M.; Raffi, I.; Lourens, L.J.; et al. Rapid acidification of the ocean during the Paleocene-Eocene thermal maximum. Science 2005, 308, 1611-1615. [CrossRef]

55. Agnini, C.; Macrì, P.; Backman, J.; Brinkhuis, H.; Fornaciari, E.; Giusberti, L.; Luciani, V.; Rio, D.; Sluijs, A.; Speranza, F. An early Eocene carbon cycle perturbation at_52.5 Ma in the Southern Alps: Chronology and biotic response. Paleoceanography 2009, 24. [CrossRef]

56. Stap, L.; Sluijs, A.; Thomas, E.; Lourens, L.J. Patterns and magnitude of deep sea carbonate dissolution during Eocene Thermal Maximum 2 and H2, Walvis Ridge, Southeastern Atlantic Ocean. Paleoceanography 2009, 24. [CrossRef]

57. Leon-Rodriguez, L.; Dickens, G.R. Constraints on ocean acidification associated with rapid and massive carbon injections: The early Paleogene record at ocean drilling program site 1215, equatorial Pacific Ocean. Palaeogeogr. Palaeoclimatol. Palaeoecol. 2010, 298, 409-420. [CrossRef]

58. Berger, W.H. Planktonic foraminifera-Selective solution and lysocline. Mar. Geol. 1970, 8, 111-138. [CrossRef]

59. Hancock, H.J.L.; Dickens, G.R. Carbonate dissolution episodes in Paleocene and Eocene sediment, Shatsky Rise, west-central Pacific. In Proceedings of the Ocean Drilling Program, Scientific Results; Bralower, T.J., Premoli Silva, I., Malone, M.J., Eds.; Texas A\&M University: College Station, TX, USA, 2005; Volume 198, pp. 1-24. Available online: http://www-odp.tamu.edu/publications/198_SR/116/116.htm (accessed on 27 February 2020). [CrossRef]

60. Nguyen, T.M.P.; Speijer, R.P. A new procedure to assess dissolution based on experiments on Pliocene-Quaternary foraminifera (ODP Leg 160, Eratosthenes Seamount, Eastern Mediterranean). Mar. Micropaleontol. 2014, 106, 22-39. [CrossRef]

61. Green, O.R. A Manual of Practical Laboratory and Field Techniques in Palaeobiology; Kluwer Academic: London, UK, 2001; Volume 538.

62. Boersma, A.; Premoli Silva, I.; Shackleton, N. Atlantic Eocene planktonic foraminiferal biogeography and stable isotopic paleoceanography. Paleoceanography 1987, 2, 287-331. [CrossRef]

63. Pearson, P.N.; Shackleton, N.J.; Hall, M.A. Stable isotope paleoecology of middle Eocene planktonic foraminifera and multispecies isotope stratigraphy, DSDP Site 523, South Atlantic. J. Foraminifer. Res. 1993, 23, 123-140. [CrossRef]

64. Luciani, V.; D'Onofrio, R.; Filippi, G.; Moretti, S. Which was the habitat of Early Eocene planktic foraminifer Chiloguembelina? Stable isotope paleobiology from Atlantic Ocean and implication for paleoceanographic reconstructions. Glob. Planet. Chang. Under review.

65. Olsson, R.K.; Hemleben, C.; Berggren, W.A.; Huber, B.T. Atlas of Paleocene Planktonic Foraminifera. In Smithsonian Contribution to Paleobiology; Smithsonian Institution Press: Washington, DC, USA, 1999; Volume 85, p. 225. 
66. Molina, E.; Alegret, L.; Apellaniz, E.; Bernaola, G.; Caballero, F.; Dinarès-Turell, J.; Hardenbol, J.; Heilmann-Clausen, C.; Larrasoaña, J.C.; Luterbacher, H.; et al. The Global Stratotype Section and Point (GSSP) for the base of the Lutetian Stage at the Gorrondatxe section, Spain. Episodes 2011, 34, 86-108. [CrossRef] [PubMed]

67. Komar, N.; Zeebe, R.E.; Dickens, G.R. Understanding long-term carbon cycle trends: The late Paleocene through the early Eocene. Paleoceanography 2013, 28, 650-662. [CrossRef]

68. Brown, J.H.; Gillooly, J.F.; Allen, A.P.; Savage, V.M.; West, G.B. Toward a metabolic theory of ecology. Ecology 2004, 85, 1771-1789. [CrossRef]

69. Olivarez Lyle, A.; Lyle, M.W. Missing organic carbon in Eocene marine sediments: Is metabolism the biological feedback that maintains end-member climates? Paleoceanography 2006, 21. [CrossRef]

70. O'Connor, M.; Piehler, M.F.; Leech, D.M.; Anton, A.; Bruno, J.F. Warming and resource availability shift food web structure and metabolism. PLoS Biol. 2009, 7. [CrossRef]

71. John, E.H.; Pearson, P.N.; Coxall, H.K.; Birch, H.; Wade, B.S.; Foster, G.L. Warm ocean processes and carbon cycling in the Eocene. Philos. Trans. R. Soc. A 2013, 371. [CrossRef] [PubMed]

72. John, E.H.; Pearson, P.N.; Coxall, H.K.; Birch, H.; Wade, B.S.; Foster, G.L. Temperature-dependent remineralization and carbon cycling in the warm Eocene oceans. Palaeogeogr. Palaeoclimatol. Palaeoecol. 2014, 413, 158-166. [CrossRef]

73. Petrizzo, M.-R.; Leoni, G.; Speijer, R.P.; De Bernardi, B.; Felletti, F. Dissolution susceptibility of some Paleogene planktonic foraminifera from ODP Site 1209 (Shatsky Rise, Pacific Ocean). J. Foraminifer. Res. 2008, 38, 357-371. [CrossRef]

74. Nguyen, T.M.P.; Petrizzo, M.-R.; Speijer, R.P. Experimental dissolution of a fossil foraminiferal assemblage (Paleocene-Eocene Thermal Maximum, Dababiya, Egypt): Implications for paleoenvironmental reconstructions. Mar. Micropaleontol. 2009, 73, 241-258. [CrossRef]

75. Nguyen, T.M.P.; Petrizzo, M.-R.; Stassen, P.; Speijer, R.P. Dissolution susceptibility of Paleocene-Eocene planktic foraminifera: Implications for palaeoceanographic reconstructions. Mar. Micropaleontol. 2011, 81, 1-21. [CrossRef]

76. D’Onofrio, R.; Luciani, V.; Giusberti, L.; Fornaciari, E.; Sprovieri, M. Tethyan planktic foraminiferal record of the early Eocene hyperthermal events ETM2, H2 and I1 (Terche section, northeastern Italy). Rend. Online Soc. Geol. Ital. 2014, 31, 66-67. [CrossRef]

77. D’Onofrio, R.; Luciani, V.; Fornaciari, E.; Giusberti, L.; Boscolo Galazzo, F.; Dallanave, E.; Westerhold, T.; Sprovieri, M.; Telch, S. Environmental perturbations at the early Eocene ETM2, H2, and I1 events as inferred by Tethyan calcareous plankton (Terche section, northeastern Italy). Paleoceanography 2016, 31, 1225-1247. [CrossRef]

78. Ruddy, G. An overview of carbon and sulfur cycling in marine sediments. In Biogeochemistry of Intertidal Sediments; Jickells, T.D., Rae, J.E., Eds.; Cambridge University Press: Cambridge, UK, 1997; pp. 98-118.

79. Berggren, W.A.; Pearson, P.N. A revised tropical to subtropical Paleogene planktic foraminiferal zonation. J. Foraminifer. Res. 2005, 35, 279-298. [CrossRef]

80. Luciani, V.; Giusberti, L.; Agnini, C.; Backman, J.; Fornaciari, E.; Rio, D. The Paleocene-Eocene Thermal Maximum as recorded by Tethyan planktonic foraminifera in the Forada section (northern Italy). Mar. Micropaleontol. 2007, 64, 189-214. [CrossRef]

81. Shackleton, N.J.; Corfield, R.M.; Hall, M.A. Stable isotope data and the ontogeny of Paleocene planktonic foraminifera. J. Foraminifer. Res. 1985, 15, 321-336. [CrossRef]

82. Pearson, P.N.; Ditchfield, P.W.; Singano, J.; Harcourt-Brown, K.G.; Nicholas, C.J.; Olsson, R.K.; Shackleton, N.J.; Hall, M.A. Warm tropical sea surface temperatures in the Late Cretaceous and Eocene epochs. Nature 2001, 413, 481-487. [CrossRef] [PubMed]

83. Quillévéré, F.; Norris, R.D.; Moussa, I.; Berggren, W.A. Role of photosymbiosis and biogeography in the diversification of early Paleogene acarininids (planktonic foraminifera). Paleobiology 2001, 27, 311-326. [CrossRef]

84. Arenillas, I.; Molina, E.; Schmitz, B. Planktic foraminiferal and ${ }^{13} \mathrm{C}$ isotopic changes across the Paleocene/Eocene boundary at Possagno (Italy). Int. J. Earth Sci. 1999, 88, 352-364. [CrossRef]

85. Molina, E.; Arenillas, I.; Pardo, A. High resolution planktic foraminiferal biostratigraphy and correlation across the Palaeocene Palaeocene/Eocene boundary in the Tethys. Bull. Soc. Géol. Fr. 1999, 170, 521-530. 
86. Ernst, S.R.; Guasti, E.; Dupuis, C.; Speijer, R.P. Environmental perturbation in the southern Tethys across the Paleocene/Eocene boundary (Dababiya, Egypt): Foraminiferal and clay mineral records. Mar. Micropaleontol. 2006, 60, 89-111. [CrossRef]

87. Guasti, E.; Speijer, R.P. The Paleocene-Eocene thermal maximum in Egypt and Jordan: An overview of the planktic foraminiferal record. Geol. Soc. Spec. Pap. 2007, 424, 53-67.

88. Schmitz, B.; Pujalte, V. Abrupt increase in seasonal extreme precipitation at the Paleocene-Eocene boundary. Geology 2007, 35, 215-218. [CrossRef]

89. Giusberti, L.; Rio, D.; Agnini, C.; Backman, J.; Fornaciari, E.; Tateo, E.; Oddone, M. Mode and tempo of the Paleocene-Eocene thermal maximum in an expanded section from the Venetian pre-Alps. Geol. Soc. Am. Bull. 2007, 119, 391-412. [CrossRef]

90. Schulte, P.; Scheibner, C.; Speijer, R.C. Fluvial discharge and sea-level changes controlling black shale deposition during the Paleocene-Eocene Thermal Maximum in the Dababiya Quarry section, Egypt. Chem. Geol. 2011, 285, 167-183. [CrossRef]

91. Slotnick, B.S.; Dickens, G.R.; Nicolo, M.J.; Hollis, C.J.; Crampton, J.S.; Zachos, J.C.; Sluijs, A. Large-amplitude variations in carbon cycling and terrestrial weathering during the latest Paleocene and earliest Eocene: The Record at Mead Stream, New Zealand. J. Geol. 2012, 120, 487-505. [CrossRef]

92. Pujalte, V.; Baceta, J.I.; Schmitz, B. A massive input of coarsegrainedsiliciclastics in the Pyrenean Basin during the PETM: The missing ingredient in a coeval abrupt change in hydrological regime. Clim. Past 2015, 11, 1653-1672. [CrossRef]

93. Hallock, P. Fluctuations in the trophic resource continuum: A factor in global diversity cycles? Paleoceanography 1987, 2, 457-471. [CrossRef]

94. Schmidt, D.N.; Thierstein, H.R.; Bollmann, J. The evolutionary history of size variation of planktic foraminiferal assemblages in the Cenozoic. Palaeogeogr. Palaeoclimatol. Palaeoecol. 2004, 212, 159-180. [CrossRef]

95. Schmidt, D.N.; Lazarus, D.; Young, J.R.; Kucera, M. Biogeography and evolution of body size in marine plankton. Earth Sci. Rev. 2006, 78, 239-266. [CrossRef]

96. Atkinson, D.; Ciotti, B.J.; Montagnes, D.J.S. Protists decrease in size linearly with temperature ca. $2.5 \%{ }^{\circ} \mathrm{C}-1$. Proc. R. Soc. Lond. B 2003, 270, 2605-2611. [CrossRef]

97. Henehan, M.J.; Evans, D.; Shankle, M.; Burke, J.; Foster, G.L.; Durrant, J.; Anagnostou, E.; Chalk, T.B.; Stewart, J.A.; Claudia, H.S.; et al. Size-dependent response of foraminiferal calcification to seawater carbonate chemistry. Biogeosceinces 2017, 14, 3287-3308. [CrossRef]

98. Zeebe, R.E.; Zachos, J.C.; Dickens, G.R. Carbon dioxide forcing alone insufficient to explain Palaeocene-Eocene Thermal Maximum warming. Nat. Geosci. 2009, 2, 576-580. [CrossRef]

99. Premoli Silva, I.; Boersma, A. Atlantic Eocene planktonic foraminiferal historical biogeography and paleohydrographic indices. Palaeogeogr. Palaeoclimatol. Palaeoecol. 1988, 67, 315-356. [CrossRef]

100. Pearson, P.N.; Coxall, H.K. Origin of the Eocene planktonic foraminifer Hantkenina by gradual evolution. Palaeontology 2014, 57, 243-267. [CrossRef]

101. Kast, E.R.; Stopler, D.A.; Auderset, A.; Higgins, J.A.; Ren, H.; Wang, X.T.; Martinez-Garcia, A.; Haug, G.H.; Sigman, D.M. Nitrogen isotope evidence for expanded suboxia in the early Cenozoic. Science 2019, 364, 386-389. [CrossRef]

(C) 2020 by the authors. Licensee MDPI, Basel, Switzerland. This article is an open access article distributed under the terms and conditions of the Creative Commons Attribution (CC BY) license (http://creativecommons.org/licenses/by/4.0/). 